\title{
Enantioselective activity of usnic acid: a comprehensive review and future perspectives
}

\author{
Agnieszka Galanty (iD · Paweł Paśko • Irma Podolak
}

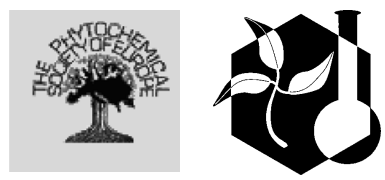

Received: 15 October 2018/Accepted: 30 March 2019/Published online: 6 April 2019

(C) The Author(s) 2019

\begin{abstract}
This review is focused on the comparison of the biological and pharmacological activities of usnic acid enantiomers. Most of the available data refer to (+)-usnic acid, while the left-handed isomer has been less often significantly studied. Special attention was paid to the experiments comparing both (+)- and (-)-usnic acid at the same time, the results of which indicated interesting differences, however no tendency as to which enantiomer was more potent could be observed. Nevertheless, more studies, especially on (-)-usnic acid, are needed to give a final explanation for the similarities and differences between both usnic acid enantiomers. These should be especially directed to steric structure-activity relationship of the enantiomers, tested under the same experimental conditions, which may help to explain the possible mechanisms of their actions.
\end{abstract}

Keywords Antibacterial · Chirality - Cytotoxic . Enantiomers · Usnic acid

A. Galanty $(\bowtie) \cdot$ I. Podolak

Department of Pharmacognosy, Faculty of Pharmacy, Jagiellonian University Medical College, Medyczna 9, 30-688 Kraków, Poland

e-mail: mfgalant@cyf-kr.edu.pl

P. Paśko

Department of Food Chemistry and Nutrition, Faculty of Pharmacy, Jagiellonian University Medical College,

Kraków, Poland

\section{Introduction}

Lichens are composed of different groups of microorganisms. According to the traditional definition, lichens are formed by the symbiotic co-existence of an algal and/or a cyanobacterial and a fungal units. However, recent reports indicate that they can be also composed of specific basidiomycete yeasts and some bacterial communities (Grube et al. 2009; Spribille et al. 2016; Schneider et al. 2016). Such broad spectrum of microorganisms makes lichens unique in terms of chemical complexity and production of specific compounds. One of such structurally unusual metabolites is usnic acid (2,6-diacetyl-7,9-dihydroxy8,9b-dimethyl-1,3(2H,9bH)-dibenzo-furandione), a yellow pigment, which exists in two enantiomeric forms, depending on the position of the methyl group at the chiral atom $9 \mathrm{~b}$ (Fig. 1).

Enantiomers do not substantially differ in terms of certain physical properties, like solubility, melting point or spectroscopic characteristics (Özek et al. 2010), but may have a different aroma or flavour (Silva et al. 2012) and also may reveal differences in their biological and pharmacological activity (Nguyen et al. 2006). The current, published reviews on usnic acid have focused mainly on the different aspects of its activity (Shrestha and St. Clair 2013; Araújo et al. 2015; Cimmino et al. 2018), but not on its enantiospecificity. Although a lot of experimental results describe a wide range of pharmacological properties of usnic acid, it is still not clear if 
<smiles>CC(=O)C1=C(O)C=C2Oc3c(C(C)=O)c(O)c(C)c(O)c3[C@@]2(C)C1=O</smiles>

A

Fig. 1 Right- (a) and left-handed (b) enantiomers of usnic acid

there are any differences between the activities of its enantiomers. The majority of the published data concern (+)-usnic acid, while the information on the potential activity of its left-handed enantiomer is scarce. Moreover, only a small number of reports refer to the activity of (+)- and (-)-usnic acid when examined within the same experiment. This makes the comparison even harder. Thus, the aim of the present review is to compile and compare the evidence available in the literature concerning the biological and pharmacological effectiveness of both usnic acid enantiomers, in order to find potential similarities or differences in their activity. Suggestions and challenges for future studies on lichen chemistry and the biological activity of usnic acid are included in this review.

\section{Materials and methods}

The following electronic English databases were searched: Pubmed, Ovid Medline, Scopus, Web of Science and Google Scholar, with no time limit. The publications have been selected by using the following keywords, combinations of "usnic acid": enantiomer, enantiospecificity, antibacterial, antifungal, antibiofilm, antioxidant, cytotoxic, photoprotective, antiviral, anitprotozoal, anti-inflammatory, analgesic, antiproliferative, antimitotic, antitumor, allergic, toxic and hepatotoxic. Reference lists of all articles were also checked for further publications. Not only were in vitro studies with usnic acid enantiomers chosen for this review, but also in vivo experiments on insects, animals and humans were taken into consideration. Although English language articles predominated in databases, some articles in Polish, German and Czech languages were also found.<smiles>CC(=O)C1=C(O)C=C(Oc2c(C)c(O)c(C)c(O)c2C(C)=O)C1(C)C</smiles>

\section{B}

For the purpose of this review, publications with the stated specific rotation of usnic acid were sourced, as well as the experiments conducted on using the $(+)$ enantiomer of commercial usnic acid from SigmaAldrich.

\section{Results}

Distribution and identification of usnic acid enantiomers

As with other chiral substances that are produced in living organisms (Finefield et al. 2012), usnic acid is present in lichen species as one enantiomer, usually with the predominance of one single isomer form, or as a scalemic mixture of enantiomers. Some examples are given in Table 1. It is noteworthy that some of the genera tend to produce exclusively (+)- or (-)-usnic acid, like Usnea and Alectoria, respectively, while in others, such as Cladonia, no specific patterns of usnic acid enantiomers biosynthesis can be identified. On the other hand, lichen taxa in which mixtures of both enantiomers were reported, namely Flavocetraria or Vulpicida, belong to the cetrarioid clade of the Parmeliaceae family. The ratio of these mixtures was determined only in a few studies (see Table 1), mostly by means of chiral HPLC separation (Kinoshita et al. 1997; Smeds and Kytöviita 2010) or electronic circular dichroism (Legouin et al. 2017). These are useful tools for the quantitative characterization of isomers. However, in the study by Bjerke et al. (2005) the authors claimed that they were able to determine the ratio of usnic acid mixture in Flavocetraria nivalis by means of HPLC with a non-chiral column, what is questionable. Ambiguous results relating to the 
Table 1 Distribution of usnic acid enantiomers in lichens

\begin{tabular}{|c|c|c|}
\hline Lichen genus & Example of species & References \\
\hline & (+)-usnic acid & \\
\hline \multirow[t]{2}{*}{ Cladonia } & Cladonia arbuscula & Einarsdottir et al. (2010) \\
\hline & Cladonia mitis & Kinoshita et al. (1997) \\
\hline \multirow[t]{2}{*}{ Ramalina } & Ramalina boninensis, $R$. pacifica, $R$. roesleri & Kinoshita et al. (1997) \\
\hline & Ramalina farinacea & Tay et al. (2004) \\
\hline \multirow[t]{2}{*}{ Usnea } & Usnea diffracta, $U$. longissima, $U$. hirta & Kinoshita et al. (1997) \\
\hline & Usnea steineri & Lucarini et al. (2012) \\
\hline Flavoparmelia & Flavoparmelia caperata & Kinoshita et al. (1997) \\
\hline \multirow[t]{2}{*}{ Xanthoparmelia } & Xanthoparmelia chlorochroa & Dailey et al. (2008) \\
\hline & (-)-usnic acid & \\
\hline \multirow[t]{3}{*}{ Cladonia } & Cladonia uncialis & Studzińska-Sroka et al. (2015) \\
\hline & Cladonia stellaris & Kinoshita et al. (1997) \\
\hline & Cladonia foliacea & Koparal (2015) \\
\hline \multirow[t]{3}{*}{ Alectoria } & Alectoria lata & Kinoshita et al. (1997) \\
\hline & Alectoria ochroleuca & Melgarejo et al. (2008) \\
\hline & Mixture & \\
\hline \multirow[t]{4}{*}{ Flavocetraria } & Flavocetraria cucculata, $F$. nivalis & Kinoshita et al. (1997) \\
\hline & The amount of (+)-usnic acid was one-fifth that of $(-)$-usnic acid & \\
\hline & F. nivalis & Bjerke et al. (2005) \\
\hline & The peak area ratio between the $(-)-$ and $(+)$-usnic acid was less than 1:100 & \\
\hline \multirow[t]{2}{*}{ Cladonia } & Cladonia stellaris & Smeds and Kytöviita (2010) \\
\hline & $0.4-10 \%$ of $(+)$-isomer of the total amount of usnic acid & \\
\hline \multirow[t]{2}{*}{ Vulpicida } & Vulpicida pinastri & Legouin et al. (2017) \\
\hline & $(+)$ - and (-)-usnic acid in a $35: 65$ ratio & \\
\hline
\end{tabular}

content of usnic acid enantiomers can be best seen with Cladonia stellaris, considered as one of the richest source of (-)-usnic acid, containing up to $2 \%$ $\mathrm{dw}$ of the compound (Rahman et al. 2008). The first report on this species by Kinoshita et al. (1997) described the presence of only one enantiomer, namely (-)-usnic acid. In a more recent work Smeds and Kytöviita (2010) discovered that C. stellaris contains both usnic acid enantiomers (Table 1). Although the predominance of the left-handed isomer is clearly seen, the (+)-usnic acid content was estimated to be as much as $10 \%$. The observed differences in the ratio of usnic acid enantiomers, obtained by both research groups, may probably result from the concentration of usnic acid solution used in the analysis. However, Smeds and Kytöviita (2010) suggest that the genetic variation of the fungal strains, forming the lichen thallus, may also influence the production of specific enantiomers.

\section{Studies comparing both usnic acid enantiomers}

A large number of studies on the activity of usnic acid, in one of its enantiomeric forms, exist. Studies comparing both enantiomers are found much less often. There were only ca. 20 papers on this subject published between 1948 and 2018.

Antibacterial, antifungal, antiviral activity

The results of the studies by Shibata et al. (1948) and Bekker et al. (2015) revealed identical antibacterial 
Table 2 Antibacterial activity of usnic acid enantiomers

\begin{tabular}{|c|c|c|c|}
\hline \multirow[t]{2}{*}{ Bacterial strain } & \multicolumn{2}{|l|}{ Activity } & \multirow[t]{2}{*}{ References } \\
\hline & $(+)$-usnic acid & $(-)$-usnic acid & \\
\hline \multirow[t]{2}{*}{ Aeromonas hydrophila } & - & MIC $1.2 \mu \mathrm{g}$ & Yilmaz et al. (2004) \\
\hline & na & - & Tay et al. (2004) \\
\hline \multirow[t]{3}{*}{ Bacillus cereus } & - & MIC $0.15 \mu \mathrm{g}$ & Yilmaz et al. (2004) \\
\hline & na & - & Tay et al. (2004) \\
\hline & - & IZ $20 \mathrm{~mm}$ at $100 \mu \mathrm{g} / \mathrm{ml}$ & Ivanova et al. (2004) \\
\hline \multirow[t]{8}{*}{ Bacillus subtilis } & - & MIC $0.61 \mu \mathrm{g}$ & Yilmaz et al. (2004) \\
\hline & IZ 23 mm $(250 \mu \mathrm{g})$ & - & Natić et al. (2004) \\
\hline & IZ 10 mm $(60 \mu \mathrm{g})$ & - & Perry et al. (1999) \\
\hline & na & - & Correche et al. (1998) \\
\hline & MIC $0.036 \mathrm{mM}$ & - & Tay et al. (2004) \\
\hline & - & IZ $35 \mathrm{~mm}$ at 100 & Ivanova et al. (2004) \\
\hline & MIC $1.2 \mu \mathrm{g} / \mathrm{ml}$ & $\mu \mathrm{g} / \mathrm{ml}$ & Paudel et al. (2010) \\
\hline & $\mathrm{IZ} 40 \mathrm{~mm}$ at $50 \mathrm{mg} / \mathrm{ml}$ & - & Melgarejo et al. (2008) \\
\hline Bacteroides thetaiotamicron & MIC $4 \mu \mathrm{g} / \mathrm{ml}$ & MIC $8 \mu \mathrm{g} / \mathrm{ml}$ & Lauterwein et al. (1995) \\
\hline Bacteroides vulgatus & MIC $4 \mu \mathrm{g} / \mathrm{ml}$ & MIC $8 \mu \mathrm{g} / \mathrm{ml}$ & Lauterwein et al. (1995) \\
\hline Bacteroides fragilis & MIC $2 \mu \mathrm{g} / \mathrm{ml}$ & MIC $1 \mu \mathrm{g} / \mathrm{ml}$ & Lauterwein et al. (1995) \\
\hline Bacteroides ruminicola ssp. brevis & MIC $8 \mu \mathrm{g} / \mathrm{ml}$ & MIC $16 \mu \mathrm{g} / \mathrm{ml}$ & Lauterwein et al. (1995) \\
\hline Bacteroides loeschii & MIC $2 \mu \mathrm{g} / \mathrm{ml}$ & MIC $2 \mu \mathrm{g} / \mathrm{ml}$ & Lauterwein et al. (1995) \\
\hline Clostridium perfringens & $\mathrm{MIC} 4 \mu \mathrm{g} / \mathrm{ml}$ & MIC $4 \mu \mathrm{g} / \mathrm{ml}$ & Lauterwein et al. (1995) \\
\hline Enterococcus durans & MIC $37.5 \mu \mathrm{g} / \mathrm{ml}$ & - & Kukla et al. (2014) \\
\hline \multirow[t]{4}{*}{ Enterococcus faecalis } & IZ $23 \mathrm{~mm}$ at $40 \mathrm{mg} / \mathrm{ml}$ & - & Elo et al. (2007) \\
\hline & MIC $4-8 \mu \mathrm{g} / \mathrm{ml}$ & MIC $4-16 \mu \mathrm{g} / \mathrm{ml}$ & Lauterwein et al. (1995) \\
\hline & MIC $6.25 \mu \mathrm{g} / \mathrm{ml}$ & - & Tozatti et al. (2016) \\
\hline & MIC $9.4-18.8 \mu \mathrm{g} / \mathrm{ml}$ & - & Kukla et al. (2014) \\
\hline \multirow[t]{3}{*}{ Enterococcus faecium } & IZ $18-23 \mathrm{~mm}$ at $40 \mathrm{mg} / \mathrm{ml}$ & - & Elo et al. (2007) \\
\hline & MIC $4-16 \mu \mathrm{g} / \mathrm{ml}$ & MIC $4-16 \mu \mathrm{g} / \mathrm{ml}$ & Lauterwein et al. (1995) \\
\hline & MIC 9.4 mg/ml & - & Kukla et al. (2014) \\
\hline \multirow[t]{6}{*}{ Escherichia coli } & na & - & Perry et al. (1999) \\
\hline & IZ $5 \mathrm{~mm}$ at $250 \mu \mathrm{g}$ & - & Natić et al. (2004) \\
\hline & na & - & Tay et al. (2004) \\
\hline & - & IZ $0-12 \mathrm{~mm}$ at $100 \mu \mathrm{g} / \mathrm{ml}$ & Ivanova et al. (2004) \\
\hline & na & - & Paudel et al. (2010) \\
\hline & MIC $1000 \mu \mathrm{g} / \mathrm{ml}$ & - & Schmeda-Hirschmann et al. (2008) \\
\hline \multirow[t]{2}{*}{ Helicobacter pylori } & $\mathrm{MIC}_{50} 0.064 \mu \mathrm{g} / \mathrm{ml}$ & - & Safak et al. (2009) \\
\hline & MIC $4-8 \mu \mathrm{g} / \mathrm{ml}$ & MIC $8-16 \mu \mathrm{g} / \mathrm{ml}$ & Lage et al. (2018) \\
\hline \multirow[t]{2}{*}{ Klebsiella pneumoniae } & na & - & Tay et al. (2004) \\
\hline & - & $\mathrm{IZ} 0 \mathrm{~mm}$ at $100 \mu \mathrm{g} / \mathrm{ml}$ & Ivanova et al. (2004) \\
\hline \multirow[t]{3}{*}{ Listeria monocytogenes } & - & MIC $0.31 \mu \mathrm{g}$ & Yilmaz et al. (2004) \\
\hline & MIC $0.018 \mathrm{mM}$ & - & Tay et al. (2004) \\
\hline & & IZ $20 \mathrm{~mm}$ at $100 \mu \mathrm{g} / \mathrm{ml}$ & Ivanova et al. (2004) \\
\hline Mycobacterium aurum & MIC $32 \mu \mathrm{g} / \mathrm{ml}$ & - & Ingolfsdottir et al. (1998) \\
\hline \multirow[t]{2}{*}{ Mycobacterium avium } & MIC $16 \mu \mathrm{g} / \mathrm{ml}$ & - & Lucarini et al. (2012) \\
\hline & MIC $100 \mu \mathrm{g} / \mathrm{ml}$ & - & Ramos and da Silva (2010) \\
\hline Mycobacterium chelonae & MIC $25 \mu \mathrm{g} / \mathrm{ml}$ & - & Ramos and da Silva (2010) \\
\hline Mycobacterium fortuitum & MIC $50 \mu \mathrm{g} / \mathrm{ml}$ & - & Ramos and da Silva (2010) \\
\hline \multirow[t]{2}{*}{ Mycobacetrium kansasii } & MIC $8 \mu \mathrm{g} / \mathrm{ml}$ & - & Lucarini et al. (2012) \\
\hline & MIC $12.5 \mu \mathrm{g} / \mathrm{ml}$ & - & Ramos and da Silva (2010) \\
\hline
\end{tabular}


Table 2 continued

\begin{tabular}{|c|c|c|c|}
\hline \multirow[t]{2}{*}{ Bacterial strain } & \multicolumn{2}{|l|}{ Activity } & \multirow[t]{2}{*}{ References } \\
\hline & $(+)$-usnic acid & $(-)$-usnic acid & \\
\hline Mycobacterium smegmatum & - & $\mathrm{IZ} 0 \mathrm{~mm}$ at $100 \mu \mathrm{g} / \mathrm{ml}$ & Ivanova et al. (2004) \\
\hline \multirow[t]{4}{*}{ Mycobacterium tuberculosis } & $1: 160000^{*}$ & $1: 160000^{*}$ & Shibata et al. (1948) \\
\hline & MIC $8 \mu \mathrm{g} / \mathrm{ml}$ & - & Lucarini et al. (2012) \\
\hline & MIC $1.56-12.5 \mu \mathrm{g} / \mathrm{ml}$ & - & Ramos and da Silva (2010) \\
\hline & IZ $8 \mathrm{~mm}$ at $75 \mathrm{nmol} / \mathrm{disc}$ & $\mathrm{IZ} 8 \mathrm{~mm}$ at $75 \mathrm{nmol} / \mathrm{disc}$ & Bekker et al. (2015) \\
\hline Propionibacterium acnes & MIC $2 \mu \mathrm{g} / \mathrm{ml}$ & MIC $2 \mu \mathrm{g} / \mathrm{ml}$ & Lauterwein et al. (1995) \\
\hline \multirow[t]{2}{*}{ Proteus vulgaris } & - & MIC $0.15 \mu \mathrm{g}$ & Yilmaz et al. (2004) \\
\hline & MIC $0.036 \mathrm{mM}$ & - & Tay et al. (2004) \\
\hline \multirow[t]{7}{*}{ Pseudomonas aeruginosa } & na & - & Perry et al. (1999) \\
\hline & IZ $5 \mathrm{~mm}$ at $250 \mu \mathrm{g}$ & - & Natić et al. (2004) \\
\hline & na & - & Tay et al. (2004) \\
\hline & - & IZ $12-18 \mathrm{~mm}$ at $100 \mu \mathrm{g} / \mathrm{ml}$ & Ivanova et al. (2004) \\
\hline & na & - & Paudel et al. (2010) \\
\hline & MIC $750 \mu \mathrm{g} / \mathrm{ml}$ & - & Schmeda-Hirschmann et al. (2008) \\
\hline & $\mathrm{IZ} 18 \mathrm{~mm}$ at $50 \mathrm{mg} / \mathrm{ml}$ & - & Melgarejo et al. (2008) \\
\hline Pseudomonas syringae & na & - & Tay et al. (2004) \\
\hline Salmonella enteritidis & MIC $750 \mu \mathrm{g} / \mathrm{ml}$ & - & Schmeda-Hirschmann et al. (2008) \\
\hline \multirow[t]{2}{*}{ Salmonella typhimurium } & na & - & Tay et al. (2004) \\
\hline & & & Ivanova et al. (2004) \\
\hline Shigella flexneri & $\mathrm{IZ} 30 \mathrm{~mm}$ at $50 \mathrm{mg} / \mathrm{ml}$ & - & Melgarejo et al. (2008) \\
\hline \multirow[t]{16}{*}{ Staphylococcus aureus } & - & MIC $2.4 \mu \mathrm{g}$ & Yilmaz et al. (2004) \\
\hline & MIC $6.06 \mu \mathrm{g} / \mathrm{ml}$ & - & Correche et al. (1998) \\
\hline & MIC $0.15 \mathrm{mM}$ & - & Tay et al. (2004) \\
\hline & IZ $13-16 \mathrm{~mm}$ at $40 \mathrm{mg} / \mathrm{ml}$ & - & Elo et al. (2007) \\
\hline & MIC $2-16 \mu \mathrm{g} / \mathrm{ml}$ & MIC $2-16 \mu \mathrm{g} / \mathrm{ml}$ & Lauterwein et al. (1995) \\
\hline & $1: 160000^{*}$ & $1: 320,000^{*}$ & \\
\hline & - & MIC $2.5 \mu \mathrm{g} / \mathrm{ml}$ & Shibata et al. (1948) \\
\hline & - & MIC $25 \mu \mathrm{g} / \mathrm{ml}$ & Studzińska-Sroka et al. (2015) \\
\hline & MIC $50 \mu \mathrm{g} / \mathrm{ml}$ & - & Gupta et al. (2012) \\
\hline & - & IZ $25-40 \mathrm{~mm}$ at $100 \mu \mathrm{g} / \mathrm{ml}$ & Tozatti et al. (2016) \\
\hline & & & Ivanova et al. (2004) \\
\hline & MIC $5.6 \mu \mathrm{g} / \mathrm{ml}$ & - & \\
\hline & MIC $100-750 \mu \mathrm{g} / \mathrm{ml}$ & - & Paudel et al. (2010) \\
\hline & MIC $64 \mu \mathrm{g} / \mathrm{ml}$ & & Schmeda-Hirschmann et al. (2008) \\
\hline & IZ $20 \mathrm{~mm}$ at $50 \mathrm{mg} / \mathrm{ml}$ & & Pompilio et al. (2016) \\
\hline & & & Melgarejo et al. (2008) \\
\hline \multirow[t]{2}{*}{ Staphylococcus epidermidis } & MIC $6.25 \mu \mathrm{g} / \mathrm{ml}$ & - & Tozatti et al. (2016) \\
\hline & - & IZ $16 \mathrm{~mm}$ at $100 \mu \mathrm{g} / \mathrm{ml}$ & Ivanova et al. (2004) \\
\hline Staphylococcus haemolyticus & MIC $25 \mu \mathrm{g} / \mathrm{ml}$ & - & Tozatti et al. (2016) \\
\hline \multirow[t]{2}{*}{ Streptococcus faecalis } & - & MIC $0.15 \mu \mathrm{g}$ & Yilmaz et al. (2004) \\
\hline & MIC $0.073 \mathrm{mM}$ & - & Tay et al. (2004) \\
\hline \multirow[t]{2}{*}{ Streptococcus pyogenes } & IZ $16-18 \mathrm{~mm}$ at $150-200 \mu \mathrm{g} / \mathrm{ml}$ & - & Nithyanand et al. (2015) \\
\hline & - & IZ $15 \mathrm{~mm}$ at $100 \mu \mathrm{g} / \mathrm{ml}$ & Ivanova et al. (2004) \\
\hline \multirow[t]{2}{*}{ Yersinia enterocolitica } & MIC $0.018 \mathrm{mM}$ & - & Tay et al. (2004) \\
\hline & - & IZ $16 \mathrm{~mm}$ at $100 \mu \mathrm{g} / \mathrm{ml}$ & Ivanova et al. (2004) \\
\hline Yersinia pseudotuberculosis & - & $\mathrm{IZ} 0 \mathrm{~mm}$ at $100 \mu \mathrm{g} / \mathrm{ml}$ & Ivanova et al. (2004) \\
\hline
\end{tabular}


activity for both enantiomers against Mycobacterium tuberculosis, while the effect against Staphylococcus aureus was higher in the case of (-)-usnic acid. Lauterwein et al. (1995) reported that both enantiomers had the same antibacterial activity against five out of ten tested bacteria strains (see Table 2). Data on another four bacterial strains showed the predominant effect of (+)-usnic acid. Only in the case of Bacterioides fragilis did the left-handed enantiomer show more activity. In a recent study of Lage et al. (2018), both usnic acid enantiomers were effective inhibitors of six clinical isolates and one reference strain of Helicobacter pylori. It is interesting to note that $(+)$ usnic acid was at least two-times more active in comparison to its (-)-enantiomer, with the exception of the reference strain and one clinical isolate, where the MIC values were equal for both enantiomers. Moreover, (+)- and (-)-usnic acid inhibited the activity of urease, an enzyme produced by $H$. pylori to colonize the stomach, by 45.3 and $33.1 \%$, respectively.

The only work comparing the antifungal activity of both compounds was the study of Halama and Van Haluwin (2004), in which no activity was shown by usnic acid enantiomers against the plant pathogenic fungal strains: Phytophthora infestans, Pythium ultimum and Ustilago maydis.

Antiviral potency of both usnic acid enantiomers was compared in two subsequent experiments in which (-)-usnic acid not only revealed significantly stronger in vitro activity against $\mathrm{A}(\mathrm{H} 1 \mathrm{~N} 1) \mathrm{pdm} 09$ influenza virus in comparison to its (+)-enantiomer, with $\mathrm{ED}_{50}$ values 14.5 and $51.7 \mu \mathrm{M}$ (Sokolov et al. 2012), respectively, but also inhibited replication of the virus in MDCK cells more effectively than $(+)$ usnic acid (Shtro et al. 2014). On the contrary, (+)usnic acid appeared to be a more potent inhibitor $\left(\mathrm{ED}_{50} 1.0 \mathrm{mg} / \mathrm{ml}\right)$ of Epstein-Barr virus activation, induced by a tumor promoter teleocidin B-4, in comparison to the left-handed enantiomer, with $\mathrm{ED}_{50}$ 1.0 and $5.0 \mu \mathrm{M}$, respectively (Yamamoto et al. 1995).

Antiprotozoal and insecticidal activity

In the study by Verotta et al. (2007), no significant differences were observed between the antiplasmodial activity of the tested enantiomers against Plasmodium falciparum, with $\mathrm{IC}_{50}$ values 15.3 and $16.1 \mu \mathrm{M}$, for (+)- and (-)-usnic acid, respectively. The antimalarial potential of both compounds was low, in comparison to chloroquine $\left(\mathrm{IC}_{50} 0.089 \mu \mathrm{M}\right)$.

Cetin et al. (2008) examined the insecticidal activity of usnic acid enantiomers against the larvae of the house mosquito Culex pipiens. After $24 \mathrm{~h}$ exposure to both compounds, strong and dose-dependent larvicidal activity was observed, with $\mathrm{LC}_{50}$ values 0.9 and $0.8 \mathrm{ppm}$ for right- and left-handed usnic acid, respectively. In the study of Emmerich et al. (1993), the toxicity and antifeedant activity of $(+)$ - and (-)-usnic acids were examined against the larvae of Spodoptera littoralis, an herbivorous insect. Although both enantiomers provoked strong mortality and growth retardation of the larvae, as a consequence of their antifeedant properties, the lefthanded enantiomer was significantly more active in comparison to its right-handed form, with $\mathrm{LD}_{50}$ value 8.6 and $90.8 \mu \mathrm{mol} / \mathrm{g} \mathrm{dw}$, respectively. The results of the study are noteworthy, as this is the only example of such vast, almost tenfold difference in the activity of both enantiomers.

\section{Phytotoxic activity}

The results presented by Romagni et al. (2000) indicated significant differences between both usnic acid enantiomers in their phytotoxic activity. Lefthanded usnic acid caused a dose-dependent bleaching of cotyledonary tissues of Lactuca sativa and Allium cepa produced in in vitro cultures. This was a result of the decrease in the amounts of chlorophyll and carotenoids. No activity was observed for (+)-usnic acid. Moreover, (-)-usnic acid inhibited the activity of protoporphyrinogen oxidase and also irreversibly inhibited 4-hydroxyphenylpyruvate dioxygenase, the enzymes involved in chlorophyll and carotenoids conversions.

\section{Cytotoxic activity}

Only a few authors compared both enantiomers using the same experimental conditions (Koparal et al. 2006; Bazin et al. 2008; Einarsdottir et al. 2010; Prokopiev et al. 2017). The results are summarized in Table 4. The influence of both compounds on a variety of murine and human cancer cell lines was presented by Bazin et al. (2008). The results indicate that (+)-usnic acid was more active against murine L1210 and human K-562 leukemias. It was also active against 
human prostate DU145 and breast MCF7cancer, while (-)-usnic acid was stronger only in the case of murine lung cancer $3 \mathrm{LL}$. It is noteworthy that both enantiomers revealed comparable cytotoxicity against human glioblastoma U251. Similarly, the study by Koparal et al. (2006), showed (+)-usnic acid to be more active, against both tested cell lines, namely murine fibroblasts V79 and human lung A549 cancer cells, than its right-handed isomer. However the results of Einarsdottir et al. (2010) showed no differences in cytotoxicity when both enantiomers were tested against human breast $\mathrm{T}$ 47-D and pancreatic Capan-2 cancer cells. In addition, the study of Prokopiev et al. (2017), suggests more pronounced cytotoxic effect of (+)-usnic acid on human blood lymphocytes.

\section{Genotoxic activity}

Prokopiev et al. (2018) indicated significant differences between genotoxic activities of both usnic acid isomers on human peripheral-blood lymphocytes. The results were more profound at higher tested concentrations of 0.15 and $0.30 \mathrm{mM}$. The effect of (-)-usnic acid was two times higher than its (+)-enantiomer, and was accompanied by the atypical DNA comets, formed with much higher frequency for the former isomer. It is noteworthy that the same authors described antigenotoxic and progenotoxic properties of both enantiomers depending on the concentration used. These compounds reduced DNA damage and the number of atypical DNA comets, provoked by the use of genotoxicants dioxidine and methyl methanesulfonate, in blood lymphocytes at concentrations up to $1 \mu \mathrm{M}$. However, at the dose of $100 \mu \mathrm{M}$ both usnic acid isomers enhanced the genotoxicity of the toxins and no significant differences between the impact of the enantiomers was observed. Similar investigations by Koparal et al. (2006) indicated that neither of the usnic acid enantiomers showed genotoxicity in human lymphocytes in the cytokinesis-blocked micronucleus assay.

\section{Allergic potency}

An early observation by Mitchell and Shibata (1969) showed the differences in immunologic response between both usnic acid isomers. Seven forest workers, developed contact allergies after working in the forested areas for a period of time. They were subjected to patch tests and in six cases, the response following application of (+)-usnic acid $(0.1 \%)$ was positive, while (-)-usnic acid, at much higher concentration $(5 \%)$ did not cause any reaction. In the case of racemic usnic acid (1\%) contact dermatitis was observed in six of the seven tested workers. The authors suggest that the allergic potential may depend on the presence of a $\mathrm{COCH}$ group at position 8 and a $\mathrm{CH}$ group at position 6, as in (+)-usnic acid. Moreover, in their previous work, the authors stated that application of usnic acid (up to 50\%) to healthy individuals, without previous contact dermatitis, caused no primary skin irritation (Mitchell and Armitage 1965). Opposite results were described by Salo et al. (1981), in a study of lichen pickers, who reacted to both usnic acid enantiomers. This observation was in agreement with the study of Hausen et al. (1993), on the sensitizing potency of both usnic acid forms on the guinea pigs by a modified FCA (Freund's complete adjuvant). Although generally weak, in comparison to standard sensitizers, (-)-usnic acid was at least two times stronger than (+)-usnic acid.

\section{Activity reported solely for (+)-usnic acid}

Antibacterial activity and antibiofilm properties

The antibacterial activity of (+)-usnic acid, presented in Table 2, ranged from significantly high to rather weak, with MIC values from 2 to $1000 \mu \mathrm{g} / \mathrm{mL}$. It is noteworthy that the antibacterial effect described by various authors for the same bacterial strain is sometimes as much as tenfold stronger. This can be seen with Staphylococcus aureus.

At present, only few studies suggest a possible mechanism for the antimicrobial activity of (+)-usnic acid. In one study, using Staphylococcus aureus MRSA strains, the authors suggest that this compound exerts its antibacterial activity by damaging the bacterial membrane. Further studies in animals (Gupta et al. 2012) showed a significant decrease in microbial load at doses of $1-5 \mathrm{mg} / \mathrm{kg}$. Another study showed that (+)-usnic acid caused a strong inhibition of RNA and DNA synthesis in Bacillus subtilis and S. aureus, but not in Escherichia coli, with only a slight effect in Vibrio harveyi. Moreover, this compound also influenced the translation process and inhibited the protein 
synthesis in B. subtilis and S. aureus (MaciągDorszyńska et al. 2014).

Several studies indicate that (+)-usnic acid may inhibit the formation of both Gram-positive and Gramnegative bacteria biofilm. In one of the study (+)usnic acid inhibited the formation of biofilm in four serotypes of Streptococcus pyogenes, responsible for pharyngitis. Not only was the biofilm biomass reduced, but there was also the decrease in protein and fatty acid components of the biofilm forming cells (Nithyanand et al. 2015).

Some practical aspects for the antibiofilm activity of (+)-usnic acid were described by Francolini et al. (2004). They showed that addition of (+)-usnic acid to polymeric materials in small medical devices prevented bacterial attachment and biofilm formation and significantly inhibited the growth of Staphylococcus aureus but not Pseudomonas aeruginosa, when compared to the control.

A similar effect was described by Kim et al. (2011), in which (+)-usnic acid added to polymethylmethacrylate (PMMA)-based bone cement significantly decreased methicillin-resistant Staphylococcus aureus biofilm formation. Stan et al. (2016), developed a nanostructured bioactive surface, consisting of zinc oxide, sodium stearate and (+)-usnic acid. The addition of the latter significantly inhibited the adherence and biofilm formation of Salmonella enterica, a known food pathogen, when compared to a surface without (+)-usnic acid.

Grumezescu et al. (2011) reported that (+)-usnic acid, formulated in nano or microparticles, significantly inhibited Staphylococcus aureus biofilm formation on coverslips coated with a tested nanofluid. Few years later the authors discovered that (+)-usnic acid, loaded into magnetic polylactic-co-glycolic acid-polyvinyl alcohol (PLGA-PVA) microspheres, inhibited not only the initial attachment of $S$. aureus to the coated surface, but also the development of mature biofilms (Grumezescu et al. 2014). Similar studies by Martinelli et al. (2014) revealed that (+)-usnic acidloaded into carboxylated poly(L-lactide) microparticles was able to inhibit 24-h Staphylococcus epidermidis biofilm, with results that were more profound than the use of (+)-usnic acid alone.

A possible mechanism for the antibiofilm activity of (+)-usnic acid against methicillin-resistant Staphylococcus aureus was recently published by Pompilio et al. (2016), who state that the effect may be a consequence of the impaired adhesion to the host matrix binding proteins, but also may be due to the decrease in lipase and thermonuclease expression.

Salta et al. (2013) described the effect of (+)-usnic acid on biofilm formation of two Gram-negative marine bacteria, Cobetia marina and Marinobacter hydrocarbonoclasticus, which cause biofouling and damage to the underwater hull of the ships. The tested compound significantly inhibited the attachment of $M$. hydrocarbonoclasticus at the highest tested concentration of $40 \mathrm{ppm}$. In the concentration range from 0.1 to $20 \mathrm{ppm}$ the adhesion remained unaffected. For $C$. marina, an enhancement in adhesion, rather than inhibitory effect, was observed for all tested concentrations.

\section{Antifungal activity and antibiofilm properties}

Antifungal activity of (+)-usnic acid is shown in Table 3. The compound appears to have rather a weak antifungal effect on a number of pathogenic and nonpathogenic fungi and yeasts, with MIC values frequently above $100 \mu \mathrm{g} / \mathrm{mL}$.

Some studies also report the influence of (+)-usnic acid on the fungal biofilm of different Candida strains. This compound not only significantly inhibited $C$. albicans biofilm formation, by reducing viability of the cells in the already existing biofilm and preventing further adhesion, but also reduced the thickness of matured biofilms (Nithyanand et al. 2015). In another study (+)-usnic acid at the concentration of $4 \mu \mathrm{g} / \mathrm{mL}$ caused significant biofilm inhibition: $71.08 \%$ for azole-resistant and $87.84 \%$ for azole-sensitive $C$. albicans strains (Peralta et al. 2017). Pires et al. (2012) examined the antibiofilm effect of (+)-usnic acid on two Candida strains, C. orthopsilosis and $C$. parapsilosis. Although the lowest concentration with $50 \%$ reduction in biofilm metabolic activity $\left(\mathrm{BEC}_{50}\right)$ had the same value for both strains $(3.9 \mu \mathrm{g} / \mathrm{mL})$, $\mathrm{BEC}_{80}$ value for $C$. parapsilosis was two times higher $(62.5 \mu \mathrm{g} / \mathrm{mL})$, in comparison to the other tested strain. Moreover, similar differences in minimum biofilm fungicidal concentration (MBFC) for C. orthopsilosis and $C$. parapsilosis indicated higher resistance of the latter strain to (+)-usnic acid. In contrast, Kvasnickova et al. (2015) demonstrated that (+)-usnic acid did not exhibit any antibiofilm activity against $C$. parapsilosis and C. krusei, up to $300 \mu \mathrm{g} / \mathrm{mL}$. 
Table 3 Antifungal activity of usnic acid enantiomers

\begin{tabular}{|c|c|c|c|}
\hline \multirow[t]{2}{*}{ Fungal strain } & \multicolumn{2}{|l|}{ Activity } & \multirow[t]{2}{*}{ References } \\
\hline & $(+)$-usnic acid & (-)-usnic acid & \\
\hline Aspergillus flavus & $\mathrm{MIC}>250 \mu \mathrm{g} / \mathrm{ml}$ & - & Schmeda-Hirschmann et al. (2008) \\
\hline Aspergillus fumigatus & $\mathrm{MIC}>250 \mu \mathrm{g} / \mathrm{ml}$ & - & Schmeda-Hirschmann et al. (2008) \\
\hline \multirow[t]{2}{*}{ Aspergillus niger } & IZ $5 \mathrm{~mm}$ at $250 \mu \mathrm{g}$ & - & Natić et al. (2004) \\
\hline & $\mathrm{MIC}>250 \mu \mathrm{g} / \mathrm{ml}$ & - & Schmeda-Hirschmann et al. (2008) \\
\hline \multirow[t]{6}{*}{ Candida albicans } & IZ $1 \mathrm{~mm}$ at $60 \mu \mathrm{g}$ & - & Perry et al. (1999) \\
\hline & MIC $0.002 \mathrm{mM}$ & - & Tay et al. (2004) \\
\hline & - & MIC $0.15 \mu \mathrm{g}$ & Yilmaz et al. (2004) \\
\hline & - & IZ $0-18 \mathrm{~mm}$ at $100 \mu \mathrm{g} / \mathrm{ml}$ & Ivanova et al. (2004) \\
\hline & na & - & Paudel et al. (2010) \\
\hline & $\mathrm{MIC}>250 \mu \mathrm{g} / \mathrm{ml}$ & - & Schmeda-Hirschmann et al. (2008) \\
\hline \multirow[t]{2}{*}{ Candida glabrata } & MIC $0.002 \mathrm{mM}$ & - & Tay et al. (2004) \\
\hline & - & MIC $0.15 \mu \mathrm{g}$ & Yilmaz et al. (2004) \\
\hline Candida orthopsilosis & MFC $125 \mu \mathrm{g} / \mathrm{ml}$ & - & Pires et al. (2012) \\
\hline Candida parapsilosis & MFC $250 \mu \mathrm{g} / \mathrm{ml}$ & - & Pires et al. (2012) \\
\hline Candida tropicalis & $\mathrm{MIC}>250 \mu \mathrm{g} / \mathrm{ml}$ & - & Schmeda-Hirschmann et al. (2008) \\
\hline Cryptococcus neoformans & $\mathrm{MIC}>250 \mu \mathrm{g} / \mathrm{ml}$ & - & Schmeda-Hirschmann et al. (2008) \\
\hline Microsporum gypseum & MIC $250 \mu \mathrm{g} / \mathrm{ml}$ & - & Schmeda-Hirschmann et al. (2008) \\
\hline Penicillium notatum & - & IZ $13 \mathrm{~mm}$ at $100 \mu \mathrm{g} / \mathrm{ml}$ & Ivanova et al. (2004) \\
\hline Phytophthora infestans & na & na & Halama and Van Haluwin (2004) \\
\hline Pythium ultimum & na & na & Halama and Van Haluwin (2004) \\
\hline \multirow[t]{2}{*}{ Saccharomyces cerevisiae } & na & - & Correche et al. (1998) \\
\hline & $\mathrm{MIC}>250 \mu \mathrm{g} / \mathrm{ml}$ & - & Schmeda-Hirschmann et al. (2008) \\
\hline Sporobolomyces salmonicolor & - & IZ $19 \mathrm{~mm}$ at $100 \mu \mathrm{g} / \mathrm{ml}$ & Ivanova et al. (2004) \\
\hline Trichophyton rubrum & MIC $100 \mu \mathrm{g} / \mathrm{ml}$ & - & Schmeda-Hirschmann et al. (2008) \\
\hline \multirow[t]{2}{*}{ Trichophyton mentagrophytes } & IZ $5 \mathrm{~mm}$ at $60 \mu \mathrm{g}$ & - & Perry et al. (1999) \\
\hline & MIC $200 \mu \mathrm{g} / \mathrm{ml}$ & - & Schmeda-Hirschmann et al. (2008) \\
\hline Ustilago maydis & na & na & Halama and Van Haluwin (2004) \\
\hline Verticillium albo-atrum & - & Growth inhibition at $100 \mu \mathrm{g} / \mathrm{disc}$ & Proksa et al. (1996) \\
\hline
\end{tabular}

Antiviral activity

Only a few experiments have been carried out on the antiviral activity of $(+)$-usnic acid. In the experiment by Perry et al. (1999), (+)-usnic acid revealed moderate activity against Herpes simplex type 1 and Polio type 1 viruses, causing over $4 \mathrm{~mm}$ inhibition zone at the concentration of $7.5 \mu \mathrm{g}$ and $30 \mu \mathrm{g}$ per disc, respectively.

A possible explanation for the antiviral action of (+)-usnic acid was suggested by Campanella et al. (2002). Mouse 3T6 fibroblasts were transfected with polyoma viruses, to check the ability of usnic acid to influence viral DNA replication, and the cells were incubated with or without (control) the tested compound. The results indicate that the compound was effective at the concentration of $5 \mu \mathrm{g} / \mathrm{mL}$. The authors showed that (+)-usnic acid strongly inhibited the replication of viral RNA, isolated from previously transfected cells.

\section{Antiprotozoal activity}

Some interesting results on antiprotozoal activity of (+)-usnic acid have been published. Two authors have studied the activity of (+)-usnic acid against a number of Leishmania species. In the study by Fournet et al. (1997), (+)-usnic acid was tested against 
promastigotes forms of Leishmania braziliensis, $L$. amazonensis and L. donovani. Following a 48-hour incubation with the tested compound, the total lysis of the parasites was observed at the concentration of $25 \mu \mathrm{g} / \mathrm{mL}$. Interestingly, the same effect was noticed for control drug pentamidine at the same concentration, while ketoconazole, also used as a control, was not active. In a similar in vitro study against three Leishmania species, namely $L$. amazonensis, $L$. brasiliensis and L. infantum, (+)-usnic acid caused a $100 \%$ lysis of the cells at the concentration of $100 \mu \mathrm{g} /$ $\mathrm{mL}$ (Schmeda-Hirschmann et al. 2008).

The antiparasitic potential of (+)-usnic acid against Toxoplasmosa gondii was examined. The tested compound inhibited the viability of the tachyzoite, in a time and dose-dependent manner, and the effect for the highest concentration used $\left(4 \times 10^{-6} \mathrm{~mol} / \mathrm{L}\right)$ was comparable to the reference drug acetylospiramycin. In addition, the compound also influenced the invasive potential of the tachyzoites into cardiofibroblasts in vitro, and the number of infected cells significantly decreased. It is worth noting that the effect for $(+)$ usnic acid was more profound than that observed for control drug (Si et al. 2016).

The antiprotozoal activity of (+)-usnic acid was also studied in vivo (Fournet et al. 1997; Si et al. 2016). The compound was administered to Leishmania amazonensis infected BALB/c mice at the dose of $25 \mathrm{mg} / \mathrm{kg}$ body weight, by various routes: orally, subcutaneously or by intralesional injections in the infected footpad. The latter treatment with (+)-usnic acid significantly decreased both lesion weight and the parasite loads in the footpad by 43.34and 72.28\%, respectively, in comparison to untreated animals The other routes of administration revealed rather an increase in both parameters. It is important to note that no toxic effects of (+)-usnic acid administration were observed, except for a slight inflammation on the footpad after the injections (Fournet et al. 1997).

In a similar study (+)-usnic acid at doses of 5, 10 and $20 \mathrm{mg} / \mathrm{kg}$, and also (+)-usnic acid formulated in liposomes at the dose of $10 \mathrm{mg} / \mathrm{kg}$, were administered intragastrically to Swiss Webster mice, infected with tachyzoites of Toxoplasmosa gondii. The compound with the highest tested concentration, and the compound formulated in liposomes, significantly prolonged the survival time of mice infected with the parasite, to 90 and $117 \%$, respectively, and the latter effect was better than this achieved with the control drug acetylospiramycin. The tested compound also caused the changes in membrane organelles of Toxoplasmosa tachyzoite, which influenced its virulence. Unfortunately, no information concerning possible toxic effects was provided by the authors ( $\mathrm{Si}$ et al. 2016).

\section{Insecticidal activity}

Sahib et al. (2008) described the activity of (+)-usnic acid against Xyleborus fornicatus, a beetle infecting Camellia sinsensis cultivars in Sri Lanka. The growth and development of the insects in various stages of their life cycle were strongly affected by the addition of the tested compound (at the concentration of 50,75 and $100 \mathrm{ppm}$ ) to the artificial dietary media. In a similar study (+)-usnic acid revealed insecticidal activity against Glyptotermes dilatatus, a termite pest of tea endemic to Sri Lanka. The starved insects were administered $10 \mathrm{mg}$ of the tested compound. This caused a significant, $80 \%$ mortality of the termites after 23 days of the exposure (Kathirgamanathar et al. 2005).

\section{Phytotoxic activity}

An inhibitory effect of (+)-usnic acid on photosynthesis due to a decrease in carotenoids and chlorophyll content in tomato plant cultivars and Quercus rotundifolia leaves has been reported (Latkowska et al. 2006; Bouaid and Vicente 1998). In a similar study (+)-usnic acid, at a very low concentration range $1-2.5 \mu \mathrm{g} / \mathrm{mL}$, inhibited the viability of the protoplasts isolated from the leaves of Nicotiana tabacum, in a dose-dependent manner. The growth of $N$. tabacum cells in vitro was also inhibited, with the total inhibitory effect seen at $5 \mu \mathrm{g} / \mathrm{mL}$ (Cardarelli et al. 1997). The tested compound also significantly inhibited the growth of Scenedesmus quadricauda, a fresh water algae genus, but the other tested genus Asterochloris erici, a lichen photobiont, was much less affected. The weaker phytotoxic effect observed in the latter may result from its evolutionary adaptation to the presence of usnic acid (Bačkor et al. 2010).

Immunomodulatory activity

The immunostimulatory potential of (+)-usnic acid on peritoneal macrophages isolated from mice has been 
reported (Santos et al. 2004). At the concentration of $100 \mu \mathrm{g} / \mathrm{mL}$, the compound stimulated hydrogen peroxide $(65.68 \mathrm{nmol})$ and nitrogen oxide $(83 \mu \mathrm{mol})$ release from the tested cells, while the reference substances used in the study (zymosan and LPS) stimulated the release of hydrogen and nitrogen reactive forms in 275.41 and $65 \mathrm{nmol}$, respectively. However, no immunomodulatory effect of (+)-usnic acid on the oxidative burst activity of whole blood phagocytic cells and there was no release of reactive oxygen radicals (Thadhani et al. 2015).

\section{Cardiac function impairment}

A recent study describes the influence of (+)-usnic acid, complexed with hydroxypropyl $\beta$-cyclodextrin for better solubility, on myocardial contractility in vitro. Isolated left atria of guinea pigs and rat ventricular cardiomyocytes were used in the study. The results indicate that (+)-usnic acid reduced atrial contraction, observed as a decrease in $\mathrm{Ca}^{2+}$ entry in myocardial cells. In isolated cardiomyocytes, the compound inhibited the L-type $\mathrm{Ca}^{2+}$ current by $73.0 \%$ at $100 \mu \mathrm{M}$ dose. In addition, (+)-usnic acid caused an irreversible myocardial contracture, characterized by a serious disturbance of the intracellular $\mathrm{Ca}^{2+}$ homeostasis. It is noteworthy that at the same time cell membrane integrity was not affected (Mendonça et al. 2017).

\section{Anti-inflammatory activity}

The anti-inflammatory activity of (+)-usnic acid was studied both in vitro and in vivo. The results of the conducted in vitro studies showed no inhibitory effect of the compound on the platelet type12(S)-lipoxygenase up to $100 \mu \mathrm{g} / \mathrm{mL}$ (Bucar et al. 2004) and only weak inhibitory activity on leukotriene B4 synthesis in polymorphonuclear leukocytes at $\mathrm{IC}_{50} 42 \pm 2.2 \mu \mathrm{M}$ (Kumar and Müller 1999a).

In an acute and chronic inflammation model, dextrorotatory usnic acid, administered per os to rats at 25,50 and $100 \mathrm{mg} / \mathrm{kg}$ doses, caused a decrease in rat paw edema and in the highest dose the effect was comparable to the reference drug, ibuprofen. In a chronic model (+)-usnic acid decreased the granulation in a dose-dependent manner and the effect was comparable to ibuprofen (Vijayakumar et al. 2000). In a similar study (+)-usnic acid, administered orally to mice in 30 and $100 \mathrm{mg} / \mathrm{kg}$ doses, revealed analgesic activity, resulting in 50 and $40 \%$ decrease in animal writhing, respectively, plus a long-term analgesic effect seen in tail-pressure test. Regarding the effect on normal body temperature and LPS-induced hyperthermia in mice, $(+)$-usnic acid showed a significant effect only on the latter, causing the decrease in temperature by 1 and $2.5{ }^{\circ} \mathrm{C}$ for 100 and $300 \mathrm{mg} / \mathrm{kg}$ doses, respectively, $4 \mathrm{~h}$ after the administration (Okuyama et al. 1995).

An interesting study in the context of potential toxicity concerns the comparison of the anti-inflammatory effect of $(+)$-usnic acid alone and encapsulated in poly- $\varepsilon$-caprolactone microsphere polymers. Both compounds, administered subcutaneously to rats in the dose of $25-50 \mathrm{mg} / \mathrm{kg}$, significantly reduced paw volume and decreased myeloperoxidase levels, whereas only the encapsulated form of $(+)$-usnic acid $(50 \mathrm{mg} / \mathrm{kg})$ significantly reduced the levels of inflammatory cytokines (IL-1 $\beta, \mathrm{TNF}-\alpha$ ) and NO. It is noteworthy that the $(+)$-usnic acid in microspheres showed a lower acute toxicity than the free form. This may have implications for further (+)-usnic acid toxicity reduction (Barbosa et al. 2017).

\section{Antimitotic activity}

The antimitotic activity of (+)-usnic acid was examined using the Allium test. The compound inhibited the growth and mitosis of the roots at the concentration of 0.0004\% (Oświecimska et al. 1987).

\section{Cytotoxic activity}

The cytotoxic activity of (+)-usnic acid has been extensively studied and the results, mainly expressed as $\mathrm{IC}_{50}$ values, are summarized in Table 4 . The compound affected murine and human cancer cells of different origin, with the activity described from high to rather moderate, while showing a significantly weaker effect on normal cells. This implicates the selectivity of (+)-usnic acid. However, vast differences were observed between $\mathrm{IC}_{50}$ values obtained for the same cancer line by different authors, as it can be seen for HeLa or MCF7 cancer cell lines (Table 4), and may be due to the different viability tests used. 
Table 4 Cytotoxic activity of usnic acid enantiomers

\begin{tabular}{|c|c|c|c|}
\hline \multirow[t]{2}{*}{ Cell line } & \multicolumn{2}{|l|}{ Activity } & \multirow[t]{2}{*}{ References } \\
\hline & $(+)$-usnic acid & (-)-usnic acid & \\
\hline \multicolumn{4}{|l|}{ Animal origin } \\
\hline $3 \mathrm{LL}$ & $\mathrm{IC}_{50} 23 \pm 6.6 \mu \mathrm{M}$ & $\mathrm{IC}_{50} 35.1 \pm 10.7 \mu \mathrm{M} \mathrm{IC}_{50}$ & Bazin et al. (2008) \\
\hline Lewis lung carcinoma & & & Bézivin et al. (2004) \\
\hline B16-F10 & $\mathrm{LC}_{50}>250 \mu \mathrm{g} / \mathrm{ml}$ & - & Brandão et al. (2013) \\
\hline \multicolumn{4}{|l|}{ Skin melanoma } \\
\hline L1210 & $\mathrm{IC}_{50} 26.4 \pm 8.5 \mu \mathrm{M}$ & $\mathrm{IC}_{50} 17.4 \pm 1.4 \mu \mathrm{M}$ & Bazin et al. (2008) \\
\hline Lymphocytic leukemia & - & $\mathrm{IC}_{50} 6 \mu \mathrm{g} / \mathrm{ml}$ & Bézivin et al. (2004) \\
\hline & - & $\begin{array}{l}95 \% \text { inhibition at } \\
1.4 \times 10^{-7} \mathrm{~mol} / \mathrm{mL}(23 \mathrm{~h})\end{array}$ & Takai et al. (1979) \\
\hline L-929 & $\mathrm{IC}_{50} 5.5 \mathrm{mg} / \mathrm{ml}$ & - & Ivanova et al. (2004) \\
\hline \multicolumn{4}{|l|}{ Fibroblasts } \\
\hline MDCK & $\mathrm{IC}_{50} 133.04 \pm 3.5 \mu \mathrm{M}$ & - & Nguyen et al. (2014) \\
\hline \multicolumn{4}{|l|}{ Madin-Darby canine kidney } \\
\hline NIH-3T3 & $\mathrm{IC}_{50}>100 \mu \mathrm{M}$ & - & Brisdelli et al. (2012) \\
\hline Fibroblasts & $\mathrm{LC}_{50}>250 \mu \mathrm{g} / \mathrm{ml}$ & - & Brandão et al. (2013) \\
\hline & $\mathrm{IC}_{50} 164.2 \pm 3.7 \mu \mathrm{M}$ & - & Nguyen et al. (2014) \\
\hline $\begin{array}{l}\text { NS20Y } \\
\text { Neuroblastoma }\end{array}$ & - & $\begin{array}{c}\mathrm{IC}_{50} 217.31 \pm 3.51(24 \mathrm{~h}) \\
52.18 \pm 1.71(48 \mathrm{~h}) \mu \mathrm{M}\end{array}$ & Koparal (2015) \\
\hline P388 & $\mathrm{IC}_{50} 16 \mu \mathrm{g} / \mathrm{ml}$ & - & Perry et al. (1999) \\
\hline \multicolumn{4}{|l|}{ Leukemia } \\
\hline Rat hepatocytes & $\mathrm{IC}_{50} 2 \mu \mathrm{M}$ & - & Sonko et al. (2011) \\
\hline RIE & $\mathrm{IC}_{50} 126 \pm 4.26 \mu \mathrm{M}$ & - & Nguyen et al. (2014) \\
\hline \multicolumn{4}{|l|}{ Intestinal epithelial } \\
\hline $\begin{array}{l}\text { V79 } \\
\text { Chinese hamster lung fibroblasts }\end{array}$ & Viability $60 \%$ at $25 \mu \mathrm{g} / \mathrm{mL}(24 \mathrm{~h})$ & $\begin{array}{l}\text { Viability } 90 \% \text { at } 25 \mu \mathrm{g} / \mathrm{mL} \\
(24 \mathrm{~h})\end{array}$ & Koparal et al. (2006) \\
\hline Vero & $\mathrm{IC}_{50}>150 \mu \mathrm{M}$ & - & Schinkovitz et al. (2014) \\
\hline \multicolumn{4}{|l|}{ Green monkey kidney } \\
\hline Wehi & $\mathrm{EC}_{50} 15.8 \mu \mathrm{M}$ & - & Dinçsoy and Cansaran Duman (2017) \\
\hline \multicolumn{4}{|l|}{ Fibrosarcoma } \\
\hline \multicolumn{4}{|l|}{ Human origin } \\
\hline $518 \mathrm{~A} 2$ & $\mathrm{IC}_{50} 5.4 \pm 0.3 \mu \mathrm{M}$ & - & Draut et al. (2017) \\
\hline \multicolumn{4}{|l|}{ Melanoma } \\
\hline A2780 & $\mathrm{IC}_{50} 75.9 \pm 2.0 \mu \mathrm{M}$ & - & Bačkorová et al. (2011) \\
\hline \multicolumn{4}{|l|}{ Ovarian carcinoma } \\
\hline A431 & $\mathrm{EC}_{50} 39 \mu \mathrm{M}, 72 \mu \mathrm{M}$ & - & Burlando et al. (2009) \\
\hline \multicolumn{4}{|l|}{ Vulvar carcinoma } \\
\hline A549 & Viability $85 \%$ at $25 \mu \mathrm{g} / \mathrm{mL}(24 \mathrm{~h})$ & Viability $100 \%$ at $25 \mu \mathrm{g} / \mathrm{mL}$ & Koparal et al. (2006) \\
\hline Lung cancer & $\mathrm{IC}_{50} 65.3 \pm 0.65 \mu \mathrm{M}$ & - & Nguyen et al. (2014) \\
\hline AGS & $\mathrm{IC}_{50} 15.01 \pm 0.52 \mu \mathrm{M}$ & - & Nguyen et al. (2014) \\
\hline \multicolumn{4}{|l|}{ Gastric cancer } \\
\hline BT-474 & $\mathrm{IC}_{50} 15.1 \mu \mathrm{M}$ & - & Ebrahim et al. (2017) \\
\hline \multicolumn{4}{|l|}{ Breast cancer } \\
\hline $\mathrm{CaCo}_{2}$ & $\mathrm{EC}_{50} 7.05 \mu \mathrm{M}$ & - & Dinçsoy and Cansaran Duman (2017) \\
\hline Colorectal adenocarcinoma & & & \\
\hline Capan-2 & $\mathrm{IC}_{50} 5.3 \mu \mathrm{g} / \mathrm{mL}$ & $\mathrm{IC}_{50} 5.0 \mu \mathrm{g} / \mathrm{mL}$ & Einarsdottir et al. (2010) \\
\hline Pancreatic cancer & & & \\
\hline
\end{tabular}


Table 4 continued

\begin{tabular}{|c|c|c|c|}
\hline \multirow[t]{2}{*}{ Cell line } & \multicolumn{2}{|l|}{ Activity } & \multirow[t]{2}{*}{ References } \\
\hline & $(+)$-usnic acid & $(-)$-usnic acid & \\
\hline $\begin{array}{l}\text { CWR22Rv1 } \\
\text { Prostate cancer }\end{array}$ & $\mathrm{IC}_{50} 24.1 \pm 0.63 \mu \mathrm{M}$ & - & Nguyen et al. (2014) \\
\hline $\begin{array}{l}\text { DLD-1 } \\
\text { Colon carcinoma }\end{array}$ & $\mathrm{IC}_{50} 19.3 \pm 5.9 \mu \mathrm{M}$ & - & Draut et al. (2017) \\
\hline $\begin{array}{l}\text { Du145 } \\
\text { Prostate cancer }\end{array}$ & $\mathrm{IC}_{50} 57.4 \pm 2.1 \mu \mathrm{M}$ & $\begin{array}{l}\mathrm{IC}_{50} 45.9 \pm 7.0 \mu \mathrm{M} \mathrm{IC}_{50} \\
\quad 15.8 \mu \mathrm{g} / \mathrm{ml}\end{array}$ & $\begin{array}{l}\text { Bazin et al. (2008) } \\
\text { Bézivin et al. (2004) }\end{array}$ \\
\hline $\begin{array}{l}\text { Ea.Hy } 926 \\
\text { Endothelial cells }\end{array}$ & $\mathrm{IC}_{50}>50 \mu \mathrm{M}$ & - & Draut et al. (2017) \\
\hline $\begin{array}{l}\text { H1299 } \\
\text { Non-small lung carcinoma }\end{array}$ & $\mathrm{IC}_{50} 22.3 \mu \mathrm{M}$ & - & Mayer et al. (2005) \\
\hline $\mathrm{HaCaT}$ & $\mathrm{IC}_{50} 2.1 \pm 0.7 \mu \mathrm{M}$ & - & Kumar and Müller (1999b) \\
\hline Keratinocytes & $\begin{array}{l}\mathrm{EC}_{50} 35 \mu \mathrm{M}, 76 \mu \mathrm{M} \\
\mathrm{IC}_{50} 185.7 \pm 4.8 \mu \mathrm{M}\end{array}$ & - & $\begin{array}{l}\text { Burlando et al. (2009) } \\
\text { Nguyen et al. (2014) }\end{array}$ \\
\hline $\begin{array}{l}\text { HCT-116 p53-/- } \\
\text { Colon carcinoma p53 null }\end{array}$ & $\mathrm{IC}_{50} 143.1 \pm 11.3 \mu \mathrm{M}$ & - & Bačkorová et al. (2011) \\
\hline $\begin{array}{l}\text { HCT-116 } \mathrm{p} 3^{+/+} \\
\text {Colon carcinoma wild type } \mathrm{p} 53\end{array}$ & $\mathrm{IC}_{50} 157.2 \pm 4.0 \mu \mathrm{M}$ & - & Bačkorová et al. (2011) \\
\hline $\begin{array}{l}\text { HCT-116 } \\
\text { Colon carcinoma }\end{array}$ & $\mathrm{IC}_{50} 17.7 \pm 5.4 \mu \mathrm{M}$ & - & Brisdelli et al. (2012) \\
\hline $\begin{array}{l}\text { HEC-50 } \\
\text { Endometrial adenocarcinoma }\end{array}$ & $70 \%$ inhibition at $50 \mu \mathrm{g} / \mathrm{ml}(46 \mathrm{~h})$ & - & Cardarelli et al. (1997) \\
\hline $\begin{array}{l}\text { HEK293T } \\
\text { Embryonic kidney }\end{array}$ & $\mathrm{IC}_{50} 85.3 \pm 0.75 \mu \mathrm{M}$ & - & Nguyen et al. (2014) \\
\hline HeLa & $\mathrm{IC}_{50} 14.9 \mu \mathrm{M}$ & - & Natić et al. (2004) \\
\hline Cervix adenocarcinoma & $\begin{array}{l}\mathrm{IC}_{50} 178.3 \pm 9.7 \mu \mathrm{M} \\
\mathrm{IC}_{50}>10 \mu \mathrm{M} \\
\mathrm{IC}_{50} 23.7 \pm 2.5 \mu \mathrm{M} \\
\mathrm{IC}_{50} 5.1 \mathrm{mg} / \mathrm{ml}\end{array}$ & $\begin{array}{l}- \\
- \\
- \\
-\end{array}$ & $\begin{array}{l}\text { Bačkorová et al. (2011) } \\
\text { Schinkovitz et al. (2014) } \\
\text { Brisdelli et al. (2012) } \\
\text { Ivanova et al. (2004) }\end{array}$ \\
\hline $\begin{array}{l}\text { Hep2C } \\
\text { Cervix carcinoma }\end{array}$ & $\mathrm{EC}_{50} 21.8 \mu \mathrm{M}$ & - & Dinçsoy and Cansaran Duman (2017) \\
\hline $\begin{array}{l}\text { HepG2 } \\
\text { Hepatoblastoma }\end{array}$ & - & $\begin{array}{l}\mathrm{IC}_{50} 160.6 \pm 4.38(24 \mathrm{~h}) \\
50.24 \pm 1.23(48 \mathrm{~h}) \mu \mathrm{M}\end{array}$ & Koparal (2015) \\
\hline & $\begin{array}{l}\mathrm{LC}_{50} 30 \mu \mathrm{M} \\
\mathrm{EC}_{50} 15.04 \mu \mathrm{M}\end{array}$ & 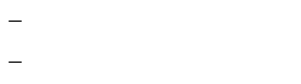 & $\begin{array}{l}\text { Sahu et al. (2011) } \\
\text { Dinçsoy and Cansaran Duman (2017) }\end{array}$ \\
\hline HL-60 & $\mathrm{IC}_{50} 14.3 \pm 0.1 \mu \mathrm{M}$ & - & Toledo Marante et al. (2003) \\
\hline Promyelotic leukemia & $\begin{array}{l}\mathrm{IC}_{50} 48.5 \pm 9.1 \mu \mathrm{M} \\
\mathrm{IC}_{50} 5.4(24 \mathrm{~h}), 1.7(48 \mathrm{~h}) \mu \mathrm{M}\end{array}$ & - & $\begin{array}{l}\text { Bačkorová et al. (2011) } \\
\text { Schinkovitz et al. (2014) }\end{array}$ \\
\hline HT-29 & $\mathrm{IC}_{50} 99.7 \pm 8.4 \mu \mathrm{M}$ & - & Bačkorová et al. (2011) \\
\hline Colon cancer & $\mathrm{IC}_{50} 95.2 \pm 0.85 \mu \mathrm{M}$ & - & Nguyen et al. (2014) \\
\hline $\begin{array}{l}\text { HUVEC } \\
\text { Umbilical vein endothelial cells }\end{array}$ & - & $\begin{array}{l}\mathrm{IC}_{50} 427.9 \pm 1.15(24 \mathrm{~h}) \\
\quad 71.5 \pm 0.19(48 \mathrm{~h}) \mu \mathrm{M}\end{array}$ & Koparal (2015) \\
\hline $\begin{array}{l}\text { Ishikawa } \\
\text { Endometrial carcinoma }\end{array}$ & $90 \%$ inhibition at $5 \mu \mathrm{g} / \mathrm{ml}(46 \mathrm{~h})$ & - & Cardarelli et al. (1997) \\
\hline $\begin{array}{l}\text { Jurkat } \\
\text { Lymphocyte leukemia }\end{array}$ & $\mathrm{IC}_{50} 76.3 \pm 8.2 \mu \mathrm{M}$ & - & Bačkorová et al. (2011) \\
\hline
\end{tabular}


Table 4 continued

\begin{tabular}{|c|c|c|c|}
\hline \multirow[t]{2}{*}{ Cell line } & \multicolumn{2}{|l|}{ Activity } & \multirow[t]{2}{*}{ References } \\
\hline & $(+)$-usnic acid & $(-)$-usnic acid & \\
\hline K-562 & $\mathrm{IC}_{50} 52.8 \pm 8.7 \mu \mathrm{M}$ & $\mathrm{IC}_{50} 21.8 \pm 3.8 \mu \mathrm{M}$ & Bazin et al. (2008) \\
\hline \multirow[t]{3}{*}{ Chronic myelogenous leukemia } & - & $\mathrm{IC}_{50} 8.2 \mu \mathrm{g} / \mathrm{ml}$ & Bézivin et al. (2004) \\
\hline & $90 \%$ inhibition at $50 \mu \mathrm{g} / \mathrm{ml}(46 \mathrm{~h})$ & - & Cardarelli et al. (1997) \\
\hline & $\mathrm{IC}_{50} 3.0 \mathrm{mg} / \mathrm{ml}$ & - & Ivanova et al. (2004) \\
\hline $\mathrm{KB}-\mathrm{V} 1 / \mathrm{Vbl}$ & $\mathrm{IC}_{50} 9.6 \pm 0.1 \mu \mathrm{M}$ & - & Draut et al. (2017) \\
\hline \multicolumn{4}{|l|}{ Cervix carcinoma } \\
\hline MCF7 & $\mathrm{IC}_{50} 18.9 \mu \mathrm{M}$ & - & Mayer et al. (2005) \\
\hline \multirow[t]{8}{*}{ Breast adenocarcinoma } & $\mathrm{IC}_{50} 105.4 \pm 16 \mu \mathrm{M}$ & $\mathrm{IC}_{50} 51.7 \pm 7.3 \mu \mathrm{M}$ & Ebrahim et al. (2017) \\
\hline & $\mathrm{IC}_{50} 94.6 \pm 7.9 \mu \mathrm{M}$ & $\mathrm{IC}_{50} 17.8 \mu \mathrm{g} / \mathrm{ml}$ & Bazin et al. (2008) \\
\hline & & & Bézivin et al. (2004) \\
\hline & $\mathrm{IC}_{50} 11.2 \pm 1.25 \mu \mathrm{M}$ & - & Bačkorová et al. (2011) \\
\hline & $\mathrm{IC}_{50} 75.7 \pm 3.4 \mu \mathrm{M}$ & - & Brisdelli et al. (2012) \\
\hline & $\mathrm{IC}_{50} 16.4 \pm 2.5 \mu \mathrm{M}$ & - & Draut et al. (2017) \\
\hline & $\mathrm{IC}_{50} 11.2 \mu \mathrm{M}$ & - & Ebrahim et al. (2017) \\
\hline & $\mathrm{IC}_{50} 34.12 \pm 1.25 \mu \mathrm{M}$ & & Zuo et al. (2015) \\
\hline MDA-MB-231 & $\mathrm{IC}_{50} 22.3 \mu \mathrm{M}$ & - & Mayer et al. (2005) \\
\hline \multirow[t]{2}{*}{ Breast cancer } & $\mathrm{IC}_{50} 13.1 \pm 0.76 \mu \mathrm{M}$ & - & Ebrahim et al. (2017) \\
\hline & $\mathrm{IC}_{50} 38.41 \pm 1.64 \mu \mathrm{M}$ & - & Zuo et al. (2015) \\
\hline MDA-MB-468 & $\mathrm{IC}_{50} 13.7 \mu \mathrm{M}$ & - & Ebrahim et al. (2017) \\
\hline \multicolumn{4}{|l|}{ Breast cancer } \\
\hline MM98 & $\mathrm{EC}_{50} 23 \mu \mathrm{M}$ & - & Burlando et al. (2009) \\
\hline \multicolumn{4}{|l|}{ Sarcomatous mesothieloma } \\
\hline Panc-1 & $\mathrm{EC}_{50} 4.3 \mu \mathrm{g} / \mathrm{ml}$ & - & Kristmundsdottir et al. (2005) \\
\hline Pancreatic carcinoma & $\mathrm{IC}_{50} 10.8 \pm 1.2 \mu \mathrm{M}$ & - & Draut et al. (2017) \\
\hline PC-3 & $\mathrm{EC}_{50} 8.2 \mu \mathrm{g} / \mathrm{ml}$ & - & Kristmundsdottir et al. (2005) \\
\hline \multicolumn{4}{|l|}{ Prostate cancer } \\
\hline $\mathrm{RD}$ & $\mathrm{EC}_{50} 22.9 \mu \mathrm{M}$ & - & Dinçsoy and Cansaran Duman (2017) \\
\hline \multicolumn{4}{|l|}{ Rhabdomyelosarcoma } \\
\hline SK-BR-3 & $\mathrm{IC}_{50} 199.2 \pm 18.8 \mu \mathrm{M}$ & - & Bačkorová et al. (2011) \\
\hline \multirow[t]{2}{*}{ Breast adenocarcinoma } & $\mathrm{IC}_{50} 14.4 \mu \mathrm{M}$ & - & Ebrahim et al. (2017) \\
\hline & $\mathrm{IC}_{50} 48.07 \pm 1.52 \mu \mathrm{M}$ & - & Zuo et al. (2015) \\
\hline SH-SY5Y & Viability $41.9 \%$ at $2 \mu \mathrm{g} / \mathrm{mL}(24 \mathrm{~h})$ & - & Rabelo et al. (2012) \\
\hline \multicolumn{4}{|l|}{ Neuroblastoma } \\
\hline $\mathrm{T}-47 \mathrm{D}$ & $\mathrm{EC}_{50} 2.9 \mu \mathrm{g} / \mathrm{ml}$ & - & Kristmundsdottir et al. (2005) \\
\hline \multirow[t]{2}{*}{ Breast cancer } & $\mathrm{IC}_{50} 4.2 \mu \mathrm{g} / \mathrm{mL}$ & $\mathrm{IC}_{50} 4.0 \mu \mathrm{g} / \mathrm{Ml}$ & Einarsdottir et al. (2010) \\
\hline & $\mathrm{IC}_{50} 15.9 \mu \mathrm{M}$ & - & Ebrahim et al. (2017) \\
\hline UACC-62 & $\mathrm{LC}_{50} 184 \mu \mathrm{g} / \mathrm{ml}$ & - & Brandão et al. (2013) \\
\hline \multicolumn{4}{|l|}{ Melanoma } \\
\hline \multirow[t]{2}{*}{ U251 glioblastoma } & $\mathrm{IC}_{50} 19.5 \pm 1.6 \mu \mathrm{M}$ & $\mathrm{IC}_{50} 19.7 \pm 4.6 \mu \mathrm{M}$ & Bazin et al. (2008) \\
\hline & - & $\mathrm{IC}_{50} 6.8 \mu \mathrm{g} / \mathrm{ml}$ & Bézivin et al. (2004) \\
\hline U87MG & $\mathrm{IC}_{50} 41.55 \mathrm{mg} / \mathrm{l}$ & - & Emsen et al. (2018) \\
\hline \multicolumn{4}{|l|}{ Glioblastoma } \\
\hline U937 & $\mathrm{IC}_{50} 14.3 \pm 0.1 \mu \mathrm{M}$ & - & Toledo Marante et al. (2003) \\
\hline Monoblastic leukemia & & & \\
\hline
\end{tabular}


Anticancer properties

Despite a great number of in vitro cytotoxicity studies of (+)-usnic acid, the data on its in vivo antitumor potential is scarce.

Intraperitoneal administration of (+)-usnic acid to sarcoma 180-bearing mice at a dose of $15 \mathrm{mg} / \mathrm{kg}$, in its free and PLGA-encapsulated form resulted in a $63 \%$ inhibition of tumor growth for the latter. In the case of the free compound, there was only $42 \%$ inhibition. It is worth noting that both tested forms of (+)-usnic acid caused no histopathological changes in liver, spleen or kidneys of the animals (Ribeiro-Costa et al. 2004). In a further experiment, under the same experimental conditions, the results were similar, with an inhibition of tumor growth of 43.3 and $69.7 \%$ for free and encapsulated (+)-usnic acid, respectively. Moreover, the decrease in hepatotoxicity for the latter was observed, with less hepatocytes vacuolization and a decrease in the levels of liver enzymes (da Silva Santos et al. 2006).

An interesting experiment was recently described by $\mathrm{Su}$ et al. (2017), who examined the effectenhancing and toxicity-reducing activity of (+)-usnic acid on hepatoma H22-bearing mice treated with bleomycin. Usnic acid (25, 50 and $100 \mathrm{mg} / \mathrm{kg}$, p.o.) administered together with bleomycin $(15 \mathrm{mg} / \mathrm{kg}$, i.p.) was significantly more effective than the cytostatic alone in inhibiting tumor growth, and also in apoptosis inducement in cancer cells. Moreover, (+)-usnic acid decreased some of the side effects of bleomycin, such as lung-tissue damage or excessive production of extracellular matrix, oxygen radical and inflammatory cytokines.

\section{Antioxidant properties}

No antioxidant effect of (+)-usnic acid in DPPH test up to $0.8 \mathrm{mM}$ was proved (Kumar and Müller 1999a; Brisdelli et al. 2012). Moreover, the compound at the concentration up to $250 \mu \mathrm{M}$ was not able to protect rat brain homogenate tissue with oxidative stress induced with $\mathrm{H}_{2} \mathrm{O}_{2} / \mathrm{Fe}^{2+}$ (Toledo Marante et al. 2003). Also, no prooxidant properties of (+)-usnic acid on lipids in model membranes were found (Kumar and Müller 1999a). In an interesting study by Suwalsky et al. (2015), (+)-usnic acid did neutralize the oxidative impact of hypochlorous acid on human erythrocytes cell membranes and also on their molecular models, at the concentration range $2-17.5 \mu \mathrm{M}$.

Antiangiogenic activity

The antiangiogenic potential of (+)-usnic acid was examined both in vitro, using the human umbilical vein endothelial cell (HUVEC) tube formation assay, and in vivo, using the zebrafish embryos or chick embryo chorioallantoic membrane (CAM) assay and the mouse corneal micropocket model. The results from the in vitro model indicate that $(+)$-usnic acid inhibited about $50 \%$ of tube formation at a concentration of $20 \mu \mathrm{M}$, after $8-12 \mathrm{~h}$ of incubation, as compared to the untreated cells (Song et al. 2012). In the in vivo study, the formation of new blood vessels was blocked by (+)-usnic acid ( $1 \mu \mathrm{g} /$ disc) in the CAM model, and in the VEGF-induced angiogenesis in the mouse cornea, there was marked inhibition. It is significant that no adverse effects such as eye inflammation or corneal edema were observed during the treatment. Moreover, the authors also described the influence of the tested compound on breast tumor angiogenesis in the mouse xenograft model and they observed that the mean integrated optical density of tumor blood vessels was obviously less in the treated (50 mg UA/kg/day intraperitoneally, 7 days), in comparison to the untreated animals (Song et al. 2012). The study on zebrafish embryos also revealed significant antiangiogenic effects, such as the reduction of intersegmental vessels, dorsal longitudinal anastomotic vessels, subintestinal veins and secondary sprouts. Side effects of pericardial edema and the impairment of blood flow were noticed, together with a curvature of the spine (Draut et al. 2017).

Genotoxic and mutagenic properties

Studies by Polat et al. (2016), using the micronucleus assay, on the right-handed enantiomer of usnic acid indicate that the compound is not genotoxic to human lymphocytes, instead it can have a protective effect in concentrations up to $200 \mu \mathrm{g} / \mathrm{mL}$ due to its antioxidant properties. Both in vitro and in vivo studies of the genotoxic potential of (+)-usnic acid, using the hamster lung fibroblasts V79 and Swiss mice model, were also described. Results obtained in the in vitro micronucleus assay indicate that the compound was not genotoxic, but it did cause DNA damage. This was 
observed in the comet assay at the doses of 60 and $120 \mu \mathrm{g} / \mathrm{mL}$. Moreover, the addition of (+)-usnic acid significantly reduced the frequency of micronuclei and DNA damage, induced by the administration of genotoxin, methyl methanesulfonate (MMS). No genotoxic effects were observed in Swiss mice given up to $200 \mathrm{mg} / \mathrm{kg} \mathrm{b.w}$. of MMS; rather a protective, antigenotoxic effect was observed following (+)usnic acid administration (Leandro et al. 2013). Mayer et al. (2005) reported on the cytotoxic, but not the genotoxic effect of (+)-usnic acid on breast cancer MCF7 cells, up to $20 \mu \mathrm{M}$. No phosphorylation of p53 at Ser15, a signal transmission after DNA damage, was observed in the cells. On the other hand, $(+)$-usnic acid, at doses of up to $20 \mathrm{mM}$ caused mutagenic and carcinogenic changes in the somatic cells of Drosophila melanogaster larvae (Machado et al. 2016).

\section{Toxicity}

In a study by Abo-Khatwa et al. (2015), (+)-usnic acid at the dose of $80-280 \mathrm{mg} / \mathrm{kg}$ was administered subcutaneously to mice to determine its potential toxicity. The median lethal dose of the compound was $180 \mathrm{mg} / \mathrm{kg}$ and the toxic symptoms included: long chalasia, ponopalmosis or spastic paralysis. These symptoms were most evident $2-5 \mathrm{~h}$ following treatment. In addition, the uncoupling of oxidative phosphorylation in the mitochondria isolated from these mice were observed. In another study (Joseph et al. 2009), the effect of (+)-usnic acid, administered per os to mice at 60-600 ppm, resulted in a 4-fold effect on the expression of several genes associated with the complexes I to IV of the mitochondrial electron transport chain. The genes involved in the Krebs cycle, fatty acid oxidation, and membrane transport were also over-expressed. The authors suggest that this may be a specific compensatory response to (+)-usnic acid, which caused an uncoupling of the proton gradient which maintains the mitochondrial membrane. The toxicity of (+)-usnic acid was also studied by Dailey et al. (2008), who administered the compound per os to domestic sheep. The toxic symptoms included: lethargy, anorexia and abdominal discomfort, and the median toxic dose was estimated between 485 and $647 \mathrm{mg} / \mathrm{kg} /$ day for 7 days.
Hepatotoxicity

Numerous studies describe toxic impact of usnic acid on liver function both in vitro and in vivo, including severe hepatotoxicity following intake of some dietary supplements for weight loss which contained this compound. This problem was discussed in detail in two recent review papers by Guo et al. (2008) and Araújo et al. (2015). It should be stressed that only some of these studies indicated the specific rotation of the tested usnic acid to be the (+)-enantiomer. In the abovementioned study on domestic sheep (see the section on 'Toxicity") the levels of creatine kinase, aspartate aminotransferase and lactate dehydrogenase were considerably elevated in the serum of the animals treated with (+)-usnic acid (Dailey et al. 2008). Similar increases in serum alanine aminotransferase and total bilirubin levels in Wistar rats treated with 100,200 and $240 \mathrm{mg} / \mathrm{kg}$ of (+)-usnic acid, together with hydropic degeneration of hepatocytes was described by $\mathrm{Lu}$ et al. (2011). However, in the aforementioned study of Silva Santos et al. (see the section on "Anticancer properties") the hepatotoxic effect of (+)-usnic acid was significantly decreased when the compound was used in the nanoencapsulated form. Moreover, the dose of ( + )-usnic acid, which was effective for tumor inhibition in the treated mice (da Silva Santos et al. 2006), was ten to 30-fold lower than that used in the toxicity studies of Lu et al. and Dailey et al., respectively. The suggested mechanism of the hepatotoxicity of usnic acid may be connected with its impact on the loss of cell membrane integrity and disruption of mitochondrial functions (Pramyothin et al. 2004), however the details of the process have not yet been defined. In our own studies on human, rat and mouse microsomes we have shown the idiosyncratic character of hepatotoxicity of usnic acid. This is due to the generation of its reactive metabolites, which form adducts with glutathione. Moreover, our results of in silico studies suggest that the hepatotoxicity can be reduced by designing usnic acid derivatives lacking ortho-methyl phenols (Piska et al. 2018).

\section{Activity reported solely for (-)-usnic acid}

The biological and pharmacological properties of (-)usnic acid are described less often in experimental papers in comparison to its right-handed enantiomer and cover only selected areas of activities. 
Antibacterial and antifungal activity

The antibacterial and antifungal activities of lefthanded usnic acid are summarized in Tables 2 and 3. No information is available on the possible inhibitory effect on bacterial or fungal biofilm formation of (-)usnic acid.

\section{Antimitotic activity}

The antimitotic activity of (-)-usnic acid was examined using the Allium test. This compound inhibited the growth and mitosis of roots at concentration of 0.25 and $2.5 \mu \mathrm{g} / \mathrm{mL}$ (Huovinen and Lampero 1989).

\section{Cytotoxic activity}

Only a few studies describe the influence of lefthanded enantiomer on cancer cells in vitro and the results are summarized in Table 4 . The cytotoxic activity may be regarded as rather high, although further studies are needed on other types of murine and human cancer cell lines of different origin to obtain more clear evidence. Moreover, the information available on the potential selectivity of (-)-usnic acid is scarce. Only two experiments have been conducted to measure its activity against normal cells, with rather moderate toxicity.

\section{Anticancer properties}

Two studies, dating back to 1970 s, concern anticancer properties of (-)-usnic acid. In the earliest experiment (-)-usnic acid, administered at doses of 20-200 mg/ $\mathrm{kg}$, caused a $35-52 \%$ increase in survival of mice with Lewis lung carcinoma, in comparison to the untreated group (Kupchan and Kopperman 1975). Further experiment by Takai et al. (1979) indicated a moderate antitumor effect of (-)-usnic acid. The compound, administered intraperitoneally to mice with P388 leukemia in a dose of $100 \mathrm{mg} / \mathrm{kg}$, extended the survival time of the animals up to $41 \%$, as compared to the controls. In both reports no information concerning the potential toxicity of the compound was provided.
Photoprotective activity

In one study (-)-usnic acid showed a protective effect on UVB irradiated human keratinocytes at a concentration of $100 \mu \mathrm{M}$ (Varol et al. 2015).

Antiangiogenic activity

In a study by Koparal (2015), (-)-usnic acid demonstrated antiangiogenic properties by inhibiting tube formation in a time and dose dependent manner, with $\mathrm{IC}_{50} 427.9$ and $71.5 \mu \mathrm{M}$ after 24 and $48 \mathrm{~h}$ of incubation, respectively.

\section{Activity reported for mixtures of both enantiomers}

In the time scope covered by this review only two reports have been published on the activity of usnic acid racemic or scalemic mixtures. In one of them the effects of racemate and the both single enantiomers were compared under the same experimental conditions. The antibacterial activity of racemic usnic acid against Mycobacterium tuberculosis did not differ from either single enantiomer. The activity of racemic usnic acid against Staphylococcus aureus was identical to this caused by (+)-usnic acid but weaker than that of the left-handed enantiomer (Shibata et al. 1948). One recent study described the antioxidant properties of usnic acid isolated from Vulpicida pinastri, which occurred as a mixture of $(+)$ - and (-)-isomers in 35/65 ratio. The mixture of both isomers revealed moderate antioxidant activity in the superoxide radical scavenging NBT test in comparison to ascorbic acid used as a positive control, with $\mathrm{IC}_{50} 24$ and $3 \mu \mathrm{g} / \mathrm{mL}$, respectively, while no activity in DPPH test was observed, with $\mathrm{IC}_{50}>500 \mu \mathrm{g} / \mathrm{mL}$ (Legouin et al. 2017). The same authors also described the photoprotective potential of the mixture of enantiomers. The tested substance revealed to be a good UVB filter, and the activity was comparable to OMC (octylmethoxycinnamate), used as a positive control. Moreover, the compound was photostable after UVA irradiation, retaining its protective properties. The authors also measured the phototoxic potential of usnic acid on irradiated keratinocytes, reporting the calculated photo-irritancy factor (PIF) as 0.7 , while the threshold value is established at 5 (Legouin et al. 2017). 


\section{Challenges and future perspectives}

Considering the perspectives for further usnic acid studies, two major points should be emphasized: the problem of the identity and purity of both enantiomers and also the comparison of their activity. Bioactivity screening of usnic acid should be preceded by careful characterization of its enantiomeric purity. Formerly recognized lichen taxa producing certain usnic acid isomer should be subjected to a more thorough examination (see the case of Cladonia stellaris in the "Distribution and identification of usnic acid enantiomers" section). It should be also noted that geographical origin of the lichen, or genetic variety of the fungal component, may also induce qualitative and quantitative differentiation between individual samples of the same species, including the production of (+)- or (-)-isomer of usnic acid. Thus, it is extremely important not only to correctly identify the lichen species to be studied, but also to determine the specific rotation of usnic acid enantiomers or the ratio of the mixture.

Although a great number of reports have been published on the biological and pharmacological activities of individual usnic acid enantiomers, a vast majority of them concern the right-handed enantiomer while (-)-usnic acid seems to be definitely less examined. One of the reasons may be the fact that the sole commercially available usnic acid is the righthanded enantiomer. The increase of the studies on both usnic acid enantiomers under the same experimental conditions is crucial for drawing any final conclusions on the superiority of any of them. The results of all the studies cited in this paper do not provide a clear answer as to whether one of the two enantiomers is more beneficial over the other. Significant and vast differences between (+)- and (-)-usnic acid were observed in only a few reports on antiviral (Sokolov et al. 2012; Yamamoto et al. 1995), insecticidal (Emmerich et al. 1993) and phytotoxic activity (Romagni et al. 2000). The predominance of neither enantiomer can be proposed on the basis of their results. Moreover, almost no information exists on the possible reasons for the differences observed between the activities of both enantiomers. The aforementioned superiority of (-)-usnic acid over the totally inactive $(+)$-usnic in terms of phytotoxic activity was connected with blocking of some plant enzymes by the former (Romagni et al. 2000). This may have be the result of some differences in the steric fitting of the enantiomers to the active site of the enzyme. Similar explanation might be proposed concerning differences in the cytotoxic impact of both usnic acid enantiomers. Cancer cells of different origin are phenotypically heterogenic and expose varied receptors on their surface, to which the enantiomers may connect and trigger different effect, depending on their steric configuration. Since the data comparing the activity of both usnic acid enantiomers under the same experimental conditions are scarce, no further speculative explanations can be drawn. Moreover, as no information exists on the steric structure-activity relationship of both usnic acid enantiomers, the problem remains an important challenge for further studies. Another promising direction for future usnic acid research should be toward the biological and pharmacological activities of its racemic mixtures. Additionally, the efforts should be made to explain the mechanism of hepatotoxicity of usnic acid and to develop the formulations or the derivatives which will provide the increase in its safety.

\section{Conclusions}

Usnic acid is a compound of unique structure, existing in the form of two enantiomers, with interesting bioactivity. Antimicrobial, cytotoxic or anti-inflammatory properties of usnic acid enantiomers seem to be the most promising, but the predominance of any of the enantiomers is still an open question. In the light of all the challenges mentioned above, accurate, wellplanned future experiments on both usnic acid enantiomers need to be conducted. Their results should enable one to determine if any of the two usnic acid enantiomers is more active than the other and can be preselected as a lead compound for future studies.

Open Access This article is distributed under the terms of the Creative Commons Attribution 4.0 International License (http://creativecommons.org/licenses/by/4.0/), which permits unrestricted use, distribution, and reproduction in any medium, provided you give appropriate credit to the original author(s) and the source, provide a link to the Creative Commons license, and indicate if changes were made. 


\section{References}

Abo-Khatwa AN, Al-Robai AA, Al-Jawhari DA (2015) The uncoupling of oxidative phosphorylation of mouse-liver mitochondria in vivo by usnic acid. JKAU 17:35-45

Araújo AAS, de Melo MGD, Rabelo TK et al (2015) Review of the biological properties and toxicity of usnic acid. Nat Prod Res 29:2167-2180

Bačkor M, Klemová K, Bačkorová M et al (2010) Comparison of the phytotoxic effects of usnic acid on cultures of freeliving alga Scenedesmus quadricauda and aposymbiotically grown lichen photobiont Trebouxia erici. J Chem Ecol 36:405-411

Bačkorová M, Bačkor M, Mikeš J et al (2011) Variable responses of different human cancer cells to the lichen compounds parietin, atranorin, usnic acid and gyrophoric acid. Toxicol In Vitro 25:37-44

Barbosa JAP, Franco ES, Silva CVNS et al (2017) Polycaprolactone microsphere polymers containing usnic acid: acute toxicity and anti-inflammatory activity. Evid Based Complement Alternat Med. https://doi.org/10.1155/2017/ 7392891

Bazin MA, Le Lamer AC, Delcros JG et al (2008) Synthesis and cytotoxic activities of usnic acid derivatives. Bioorgan Med Chem 16:6860-6866

Bekker OB, Sokolov DN, Luzina OA et al (2015) Synthesis and activity of (+)-usnic acid and (-)-usnic acid derivatives containing 1,3-thiazole cycle against Mycobacterium tuberculosis. Med Chem Res. https://doi.org/10.1007/ s00044-015-1348-2

Bézivin C, Tomasi S, Rouaud I et al (2004) Cytotoxic activity of compounds from the lichen: Cladonia convoluta. Planta Med 70:874-877

Bjerke JW, Elvebakk A, Dominguez E et al (2005) Seasonal trends in usnic acid concentrations of arctic, alpine and patagonian populations of the lichen Flavocetraria nivalis. Phytochemistry 66:337-344

Bouaid K, Vicente C (1998) Chlorophyll degradation effected by lichen substances. Ann Bot Fennici 35:71-74

Brandão LFG, Alcantara GB, Matos MFC et al (2013) Cytotoxic evaluation of phenolic compounds from lichens against melanoma cells. Chem Pharm Bull 61:176-183

Brisdelli F, Perilli M, Sellitri D et al (2012) Cytotoxic activity and antioxidant capacity of purified lichen metabolites: an in vitro study. Phytother Res 27:431-437

Bucar F, Schneider I, Ögmundsdottir H et al (2004) Anti-proliferative lichen compounds with inhibitory activity on 12(S)-HETE production in human platelets. Phytomedicine 11:602-606

Burlando B, Ranzato E, Volante A et al (2009) Antiproliferative effects on tumor cells and promotion of keratinocytes wound healing by different lichen compounds. Planta Med 75:607-613

Campanella L, Delfini M, Ercole P et al (2002) Molecular characterization and action of usnic acid, a dug that inhibits proliferation of mouse polyomavirus in vitro and whose main target is RNA transcription. Biochimie 84:329-334

Cardarelli M, Serino G, Campanella L et al (1997) Antimitotic effects of usnic acid on different biological systems. Cell Mol Life Sci 53:667-672
Cetin H, Tufan-Cetin O, Turk AO et al (2008) Insecticidal activity of major lichen compounds, (-) and (+)-usnic acid, against the larvae of house mosquito, Culex pipiens. Parasitol Res 102:1277-1279

Cimmino A, Nimis PL, Masi M et al (2018) Have lichenized fungi delivered promising anticancer small molecules? Phytochem Rev. https://doi.org/10.1007/s11101-0189577-x

Correche ER, Carrasco M, Escudero ME et al (1998) Study of the cytotoxic and antimicrobial activities of usnic acid and derivatives. Fitoterapia 69:493-501

da Silva Santos NP, Nascimento SC, Wanderley MSO et al (2006) Nanoencapsulation of usnic acid: an attempt to improve antitumor activity and reduce hepatotoxicity. Eur J Pharm Biopharm 64:154-160

Dailey RN, Montgomery DL, Ingram JT et al (2008) Toxicity of the lichen secondary metabolite (+)-usnic acid in domestic sheep. Vet Pathol 45:19-25

Dinçsoy AB, Cansaran Duman D (2017) Changes in apoptosisrelated gene expression profiles in cancer cell lines exposed to usnic acid lichen secondary metabolite. Turk J Biol 41:484-493

Draut H, Rehm T, Begemann G (2017) Antiangiogenic and toxic effects of genistein, usnic acid, and their copper complexes in zebrafish embryos at different developmental stages. Chem Biodivers. https://doi.org/10.1002/cbdv. 201600302

Ebrahim HY, Akl MR, Elsayed HE et al (2017) Usnic acid benzylidene analogues as potent mechanistic target of rapamycin inhibitors for the control of breast malignancies. J Nat Prod 80:932-952

Einarsdottir E, Groeneweg J, Björnsdottir GG et al (2010) Cellular mechanisms of the anticancer effects of the lichen compound usnic acid. Planta Med 76:1-6

Elo H, Matikainen J, Pelttari E (2007) Potent activity of the lichen antibiotic $(+)$-usnic acid against clinical isolates of vancomycin-resistant enterococci and methicillin-resistant Staphylococcus aureus. Naturwissenschaften 94:465-468

Emmerich R, Giez I, Lange OL et al (1993) Toxicity and antifeedant activity of lichen compounds against the polyphagous herbivorous insect Spodoptera littoralis. Phytochemistry 33:1389-1394

Emsen B, Aslan A, Turkez H et al (2018) The anti-cancer efficacies of diffractaic, lobaric, and usnic acid: in vitro inhibition of glioma. J Can Res Ther 14:941-951

Finefield JM, Sherman DH, Kreitman M et al (2012) Enantiomeric natural products: occurrence and biogenesis. Angew Chem Int Ed Engl 14:4802-4836

Fournet A, Ferreira ME, Rojas de Arias A et al (1997) Activity of compounds isolated from Chilean lichens against experimental cutaneous leishmaniosis. Comp Biochem Physiol 116C:51-54

Francolini I, Norris P, Piozzi A et al (2004) Usnic acid, a natural antimicrobial agent able to inhibit bacterial biofilm formation on polymer surfaces. Antimicrob Agents Chemoth 48:4360-4365

Grube M, Cardinale M, de Castro Vieira, Jr J et al (2009) Species-specific structural and functional diversity of bacterial communities in lichen symbioses. ISME J 3:1105-1115

Grumezescu AM, Saviuc C, Chifiriuc MC et al (2011) Inhibitory activity of $\mathrm{Fe}_{3} \mathrm{O}_{4} /$ oleic acid/usnic acid—core/shell/extra- 
shell nanofluid on $S$. aureus biofilm development. IEEE Trans Nano Bio Sci 10:269-274

Grumezescu V, Holban AM, Grumezescu AM et al (2014) Usnic acid-loaded biocompatible magnetic PLGA-PVA microsphere thin films fabricated by MAPLE with increased resistance to staphylococcal colonization. Biofabrication 6 (12 pp) https://doi.org/10.1088/1758-5082/6/ 3/035002

Guo L, Shi Q, Fang J-L et al (2008) Review of usnic acid and Usnea barbata toxicity. J Environ Sci Health C 26:317-338

Gupta VK, Verma S, Gupta S et al (2012) Membrane-damaging potential of natural L-(-)-usnic acid in Staphylococcus aureus. Eur J Clin Microbiol Infect Dis. https://doi.org/10. 1007/s10096-012-1706-7

Halama P, Van Haluwin C (2004) Antifungal activity of lichen extracts and lichenic acids. Bio Control 49:95-107

Hausen BM, Emde L, Marks V (1993) An investigation of the allergenic constituents of Cladonia stellaris (Opiz) Pous\&VeŽda ('silvermoss', 'reindeermoss' or 'reindeerlichen'). Contact Dermat 28:70-76

Huovinen K, Lampero M (1989) Usnic acid as a mitotic inhibitor in the Allium test. Planta Med 55:98

Ingolfsdottir K, Chung GAC, Skulason VG et al (1998) Antimycobacterial activity of lichen substances in vitro. Eur J Pharm Sci 6:141-144

Ivanova V, Graefe U, Schlegel B et al (2004) Usnic acid, metabolite from Neuropogon sp., an Antarctic lichen isolation, structure elucidation and biological activity. Biotechnol Biotechnol Equip 18:66-71

Joseph A, Lee T, Moland CL et al (2009) Effect of (+)-usnic acid on mitochondrial functions as measured by mitochondria-specific oligonucleotide microarray in liver of B6C3F1 mice. Mitochondrion 9:149-158

Kathirgamanathar S, Williams DE, Andersen RJ et al (2005) $\beta$ orcinol depsidones from the lichen Usnea sp. from Sri Lanka. Nat Prod Res 19:695-701

Kim S, Greenleaf R, Miller MC et al (2011) Mechanical effects, antimicrobial efficacy and cytotoxicity of usnic acid as a biofilm prophylaxis in PMMA. Mater Med, J Mater Sci. https://doi.org/10.1007/s10856-011-4445-x2011

Kinoshita Y, Yamamoto Y, Yoshimura J et al (1997) Distribution of optical isomers of usnic and isousnic acids analysed by HPLC. J Hattori Bot Lab 83:173-178

Koparal AT (2015) Anti-angiogenic and antiproliferative properties of the lichen substances (-)-usnic acid and vulpinic acid. Z Naturforsch 70c:159-164

Koparal AT, Ayaz Tüylü B, Türk H (2006) In vitro cytotoxic activities of (+) usnic and (-) usnic acid on V79, A549 and human lymphocyte cells and their non-genotoxicity on human lymphocytes. Nat Prod Res 20:1300-1307

Kristmundsdottir T, Jonsdottir E, Ogmundsdottir HM et al (2005) Solubilization of poorly soluble lichen metabolites for biological testing on cell lines. Eur $\mathrm{J}$ Pharm Sci 24:539-543

Kukla R, Mazurova J, Bostikova V et al (2014) In vitro antibacterial activity of usnic acid and octylgallate against resistant Enterococcus strains. Mil Med Sci Lett (Voj Zdrav Listy) 83:104-113
Kumar SKC, Müller K (1999a) Lichen metabolites: 1. Inhibitory action against leukotriene B4 biosynthesis by a nonredox mechanism. J Nat Prod 62:817-820

Kumar SKC, Müller K (1999b) Lichen metabolites 2: antiproliferative and cytotoxic activity of gyrophoric, usnic and diffractic acid on human keratinocytes growth. J Nat Prod 62:821-823

Kupchan SM, Kopperman HL (1975) Usnic acid: tumour inhibition isolated from lichens. Experientia 31:625

Kvasnickova E, Matatkova O, Cejkova A et al (2015) Evaluation of baicalein, chitosan and usnic acid effect on Candida parapsilosis and Candida krusei biofilm using a Cellavistadevice. J Microbiol Methods 118:106-112

Lage TCA, Maciel TMS, Mota YCC et al (2018) In vitro inhibition of Helicobacter pylori and interaction studies of lichen natural products with jack bean urease. New J Chem 42:5356-5366

Latkowska E, Lechowski Z, Bialczyk J et al (2006) Photosynthesis and water relations in tomato plants cultivated longterm in media containing (+)-usnic acid. J Chem Ecol 32:2053-2066

Lauterwein M, Oethinger M, Belsner K et al (1995) In vitro activities of the lichen secondary metabolites vulpinic acid, $(+)$ - and (-)-usnic acid against aerobic and anaerobic microorganisms. Antimicrob Agents Chemoth 39:2541-2543

Leandro LF, Munari CC, Lucatti Sato VLF et al (2013) Assessment of the genotoxicity and antigenotoxicity of (+)-usnic acid in V79 cells and Swiss mice by the micronucleus and comet assays. Mutat Res 753:101-106

Legouin B, Lohézic-Le Dévéhat F, Ferron S et al (2017) Specialized metabolites of the lichen Vulpicida pinastri act as photoprotective agents. Molecules 22:1162. https://doi. org/10.3390/molecules22071162

Lu X, Zhao Q, Tian Y et al (2011) A metabonomic characterization of (+)-usnic acid-induced liver injury by gas chromatography-mass spectrometry-based metabolic profiling of the plasma and liver in rat. Int J Toxicol 30:478-491

Lucarini R, Tozatti MG, de Oliveira Salloum AI et al (2012) Antimycobacterial activity of Usnea steineri and its major constituent (+)-usnic acid. Afr J Biotechnol 11:4636-4639

Machado NM, de Rezende AAA, Nepomuceno JC et al (2016) Evaluation of mutagenic, recombinogenic and carcinogenic potential of (+)-usnic acid in somatic cells of Drosophila melanogaster. Food Chem Toxicol 96:226-233

Maciąg-Dorszyńska M, Węgrzyn G, Guzow-Krzemińska B (2014) Antibacterial activity of lichen secondary metabolite usnic acid is primarily caused by inhibition of RNA and DNA synthesis. FEMS Microbiol Lett 353:57-62

Martinelli A, Bakry A, D'Ilario L et al (2014) Release behavior and antibiofilm activity of usnic acid-loaded carboxylated poly(L-lactide) microparticles. Eur J Pharm Biopharm 88:415-423

Mayer M, O’Neill MA, Murray KE et al (2005) Usnic acid: a non-genotoxic compound with anti-cancer properties. Anticancer Drugs 16:805-809

Melgarejo M, Sterner O, Castro JV et al (2008) More investigations in potent activity and relationship structure of the lichen antibiotic (+)-usnic acid and its derivate dibenzoylusnic acid. Rev Boliv Quím 25:24-29 
Mendonça SCS, Vasconcelos CML, Cruz JS et al (2017) (+)Usnic acid isolated from the lichen Cladonia substellata impairs myocardial contractility. Planta Med Int Open 4:e59-e65. https://doi.org/10.1055/s-0043-114423

Mitchell JC, Armitage JS (1965) Dermatitis venenata from lichens; biology of lichens related to criteria for diagnosis of occupational dermatitis and to industrial exposure risk. Arch Environ Health 11:701-709

Mitchell JC, Shibata S (1969) Immunologic activity of some substances derived from lichenized fungi. J Invest Dermatol 52:517-520

Natić M, Tešić Z, Andelković K et al (2004) Synthesis and biological activity of $\mathrm{Pd}(\mathrm{II})$ and $\mathrm{Cu}(\mathrm{II})$ complexes with acylhydrazones of usnic acid. Syn React Inorg Met 34:101-113

Nguyen LA, He H, Pham-Huy Ch (2006) Chiral drugs: an overview. Int J Biomed Sci 2:85-100

Nguyen TT, Yoon S, Yang Y et al (2014) Lichen secondary metabolites in Flavocetraria cucullata exhibit anti-cancer effects on human cancer cells through the induction of apoptosis and suppression of tumorigenic potentials. PLoS ONE 9(10):e111575. https://doi.org/10.1371/journal.pone. 0111575

Nithyanand P, Shafreen RMB, Muthamil S et al (2015) Usnic acid, a lichen secondary metabolite inhibits group A Streptococcus biofilms. Antonie Van Leeuwenhoek 107:263-272

Okuyama E, Umeyama K, Yamazaki M et al (1995) Usnic acid and diffractic acid as analgesic and antipyretic components of Usnea diffracta. Planta Med 61:113-115

Oświecimska M, Janeczko Z, Sendra J (1987) Antimitotic activity of some Cladonia species native to Poland. Part IV. The biological activity of usnic acid isolated from Cladonia sylvatica L. Hoffm. Herba Pol 33:205-209

Özek T, Tabanca N, Demirci F et al (2010) Enantiomeric distribution of some linalool containing essential oils and their biological activities. Rec Nat Prod 4:180-192

Paudel B, Bhattarai HD, Lee HK et al (2010) Antibacterial activities of ramalin, usnic acid and its three derivatives isolated from the Antarctic lichen Ramalina terebrata. Z Naturforsch 65c:34-38

Peralta MA, da Silva MA, Ortega MG et al (2017) Usnic acid activity on oxidative and nitrosative stress of azole-resistant Candida albicans biofilm. Planta Med 83:326-333

Perry NB, Benn MH, Brennan NJ et al (1999) Antimicrobial, antiviral and cytotoxic activity of New Zeland lichens. Lichenologist 31:627-636

Pires RH, Lucarini R, Mendes-Giannini MJS (2012) Effect of usnic acid on Candida orthopsilosis and C. parapsilosis. Antimicrob Agents Chemoth 56:595-597

Piska K, Galanty A, Koczurkiewicz P et al (2018) Usnic acid reactive metabolites formation in human, rat, and mice microsomes. Implication for hepatotoxicity. Food Chem Toxicol 120:112-118

Polat Z, Aydın E, Türkez H et al (2016) In vitro risk assessment of usnic acid. Toxicol Ind Health 32:468-475

Pompilio A, Riviello A, Crocetta V et al (2016) Evaluation of antibacterial and antibiofilm mechanisms by usnic acid against methicillin-resistant Staphylococcus aureus. Future Microbiol 11:10. https://doi.org/10.2217/fmb2016-0049
Pramyothin P, Janthasoot W, Pongnimitprasert N et al (2004) Hepatotoxic effect of (+)usnic acid from Usnea siamensis Wainio in rats, isolated rat hepatocytes and isolated rat liver mitochondria. J Ethnopharmacol 90:381-387

Prokopiev IA, Filippov EV, Filippova GV et al (2017) Genotoxicity of usnic acid enantiomers in vitro in human peripheral-blood lymphocytes. Cell Tissue Biol 11:141-146

Prokopiev IA, Filippov EV, Filippova GV et al (2018) Pro/ antigenotoxic activity of usnic acid enantiomers in vitro. Bull Exp Biol Med 164:312-315

Proksa B, Šturdíková M, Prónayová N et al (1996) (-)-Usnic acid and its derivatives. Their inhibition of fungal growth and enzyme activity. Pharmazie 51:195-196

Rabelo TK, Zeidán-Chuliá F, Vasques LM et al (2012) Redox characterization of usnic acid and its cytotoxic effect on human neuron-like cells (SH-SY5Y). Toxicol In Vitro 26:304-314

Rahman M, Falck-Ytter AB, Antonsen ØG et al (2008) Reindeer lichen (Cladonia stellaris) from a Norwegian mountain region as a sustainable source of usnic acid. Int $\mathrm{J}$ Appl Res Nat Prod 8:17-23

Ramos DF, da Silva PEA (2010) Antimycobacterial activity of usnic acid against resistant and susceptible strains of $M y$ cobacterium tuberculosis and non-tuberculous mycobacteria. Pharm Biol 48:260-263

Ribeiro-Costa RM, Alves AJ, Santos NP et al (2004) In vitro and in vivo properties of usnic acid encapsulated into PLGAmicrospheres. J Microencapsul 21:371-384

Romagni JG, Meazza G, Nanayakkara NP et al (2000) The phytotoxic lichen metabolite, usnic acid, is a potent inhibitor of plant p-hydroxyphenyl pyruvate dioxygenase. FEBS Lett 480:301-305

Safak B, Ciftci IH, Ozdemir M et al (2009) In vitro anti-Helicobacter pylori activity of usnic acid. Phytother Res 23:955-957

Sahib K, Kularatne NS, Kumar S et al (2008) Effect of (+)-usnic acid on the shot-hole borer (Xyleborus fornicatus) of tea. J Natn Sci Foundation Sri Lanka 36:335-336

Sahu SC, Amankwa-Sakyi M, O’Donnell MW Jr et al (2011) Effects of usnic acid exposure on human hepatoblastoma HepG2 cells in culture. J Appl Toxicol. https://doi.org/10. 1002/jat. 1721

Salo H, Hannuksela M, Hausen B (1981) Lichen picker's dermatitis (Cladonia alpestris (L) Rab.). Contact Derm 7:9-13

Salta M, Wharton JA, Dennington SP et al (2013) Anti-biofilm performance of three natural products against initial bacterial attachment. Int J Mol Sci 14:21757-21780

Santos LC, Honda NK, Carlos IZ et al (2004) Intermediate reactive oxygen and nitrogen from macrophages induced by Brazilian lichens. Fitoterapia 75:473-479

Schinkovitz A, Kaur A, Urban E et al (2014) Cytotoxic constituents from Lobaria scrobiculata and a comparison of two bioassays for their evaluation. J Nat Prod 77:1069-1073

Schmeda-Hirschmann G, Tapial A, Lima B et al (2008) A new antifungal and antiprotozoal depside from the Andean lichen Protousnea poeppigii. Phytother Res 22:349-355

Schneider K, Resl P, Spribille T (2016) Escape from the cryptic species trap: lichen evolution on both sides of a cyanobacterial acquisition event. Mol Ecol 25:3453-3468 
Shibata S, Ukita T, Tamura T (1948) Relation between chemical constitutions and antibacterial effects of usnic acid and its derivatives. Japan Med J 1:152-154

Shrestha G, St. Clair LL (2013) Lichens: a promising source of antibiotic and anticancer drugs. Phytochem Rev 12:229-244

Shtro A, Zarubaev VV, Luzina OA et al (2014) Novel derivatives of usnic acid effectively inhibiting reproduction of influenza A virus. Bioorg Med Chem 22:6826-6836

Si K, Wei L, Yu X et al (2016) Effects of (+)-usnic acid and (+)usnic acid-liposome on Toxoplasma gondii. Exp Parasitol 166:68-74

Silva ACR, Lopes PM, Azevedo MMB et al (2012) Biological activities of $\alpha$-pinene and $\beta$-pinene enantiomers. Molecules 17:6305-6316

Smeds AI, Kytöviita M-M (2010) Determination of usnic and perlatolic acids and identification of olivetoric acids in Northern reindeer lichen (Cladonia stellaris) extracts. Lichenologist 42:739-749

Sokolov DN, Zarubaev VV, Shtro AA et al (2012) Anti-viral activity of (-)- and (+)-usnic acids and their derivatives against influenza virus A(H1N1). Bioorg Med Chem Lett 22:7060-7064

Song Y, Dai F, Zhai D et al (2012) Usnic acid inhibits breast tumor angiogenesis and growth by suppressing VEGFR2mediated AKT and ERK1/2 signalling pathways. Angiogenesis. https://doi.org/10.1007/s10456-012-9270-4

Sonko BJ, Schmitt TC, Guo L et al (2011) Assessment of usnic acid toxicity in rat primary hepatocytes using $13 \mathrm{C}$ isotopomer distribution analysis of lactate, glutamate and glucose. Food Chem Toxicol 49:2968-2974

Spribille T, Tuovinen V, Resl P et al (2016) Basidiomycete yeasts in the cortex of ascomycete macrolichens. Science 353:488-492

Stan MS, Constanda S, Grumezescu V et al (2016) Thin coatings based on ZnO@C18-usnic acid nanoparticles prepared by MAPLE inhibit the development of Salmonella enterica early biofilm growth. Appl Surf Sci 374:318-325

Studzińska-Sroka E, Hołderna-Kędzia E, Galanty A et al (2015) In vitro antimicrobial activity of extracts and compounds isolated from Cladonia uncialis. Nat Prod Res 29:2302-2307

Su Z-Q, Liu H-Y, Guo H-Z et al (2017) Effect-enhancing and toxicity-reducing activity of usnic acid in ascetic tumorbearing mice treated with bleomycin. Int Immunopharm 46:146-155

Suwalsky M, Jemiola-Rzeminska M, Astudillo C et al (2015) An in vitro study on the antioxidant capacity of usnic acid on human erythrocytes and molecular models of its membrane. Biochim Biophys Acta 1848:2829-2838

Takai M, Uehara Y, Beisler JA (1979) Usnic acid derivatives as potential antineoplastic agents. J Med Chem 22:1380-1384

Tay T, Türk AÖ, Yilmaz M et al (2004) Evaluation of the antimicrobial activity of the acetone extract of the lichen Ramalina farinacea and its (+)-usnic acid, norstictic acid and protocetraric acid constituents. $\mathrm{Z}$ Naturforsch 59c:384-388

Thadhani VM, Mesaik MA, Asif M et al (2015) Immunomodulatory activities of some common lichen metabolites. Int $\mathrm{J}$ Pharm Pharm Sci 7:144-147

Toledo Marante FJ, Garcia Castellano A, Rosas FE et al (2003) Identification and quantitation of allelochemicals from the lichen Lethariella canariensis: phytotoxicity and antioxidative activity. J Chem Ecol 29:2049-2071

Tozatti MG, Ferreira DS, Flauzino FG et al (2016) Activity of the lichen Usnea steineri and its major metabolites against Gram-positive, multidrug-resistant bacteria. Nat Prod Commun 11:493-496

Varol M, Tay T, Candan M et al (2015) Evaluation of the sunscreen lichen substances usnic acid and atranorin. Biocell 39:25-31

Verotta L, Appendino G, Bombardelli E et al (2007) In vitro antimalarial activity of hyperforin, a prenylated acylphloroglucinol. A structure-activity study. Bioorg Med Chem Lett 17:1544-1548

Vijayakumar CS, Viswanathan S, Kannappa Reddy M et al (2000) Anti-inflammatory activity of (+)-usnic acid. Fitoterapia 71:564-566

Yamamoto Y, Miura Y, Kinoshita Y et al (1995) Screening of tissue cultures and thalli of lichens and some of their active constituents for inhibition of tumor promoter-induced Epstein-Barr virus activation. Chem Pharm Bull 43:1388-1390

Yilmaz M, Türk AÖ, Tay T et al (2004) The antimicrobial activity of extracts of the lichen Cladonia foliacea and its (-)-usnic acid, atranorin and fumarprotocetraric acid constituents. Z Naturforsch 59c:249-254

Zuo S-T, Wang L-P, Zhang Y et al (2015) Usnic acid induces apoptosis via an ROS-dependent mitochondrial pathway in human breast cancer cells in vitro and in vivo. RSC Adv 5:153-162

Publisher's Note Springer Nature remains neutral with regard to jurisdictional claims in published maps and institutional affiliations. 